\title{
The visibility of philosophy of science in the sciences, 1980-2018
}

\author{
Mahdi Khelfaoui ${ }^{1}$, Yves Gingras ${ }^{2}$, Maël Lemoine ${ }^{3}$, Thomas Pradeu ${ }^{4}$
}

\begin{abstract}
In this paper, we provide a macro level analysis of the visibility of philosophy of science in the sciences over the last four decades. Our quantitative analysis of publications and citations of philosophy of science papers, published in 17 main journals representing the discipline, contributes to the longstanding debate on the influence of philosophy of science on the sciences. It reveals the global structure of relationships that philosophy of science maintains with science, technology, engineering and mathematics (STEM) and social sciences and humanities (SSH) fields. Explored at the level of disciplines, journals and authors, this analysis of the relations between philosophy of science and a large and diversified array of disciplines allows us to answer several questions: what is the degree of openness of various disciplines to the specialized knowledge produced in philosophy of science? Which STEM and SSH fields and journals have privileged ties with philosophy of science? What are the characteristics, in terms of citation and publication patterns, of authors who get their philosophy of science papers cited outside their field? Complementing existing qualitative inquiries on the influence of specific authors, concepts or topics of philosophy of science, the bibliometric approach proposed in this paper offers a comprehensive portrait of the multiple relationships that links philosophy of science to the sciences.
\end{abstract}

Keywords: philosophy of science, visibility, sciences, bibliometrics, citation analysis.

\section{Introduction}

Philosophers, and other scholars of the social sciences and humanities, have only recently started to use quantitative methods to analyze the structure of the field of philosophy and its different subfields. For instance, using bibliographic coupling, Noichl (2019) found that the disciplinary structure of philosophy was quite cohesive, and that the

\footnotetext{
${ }^{1}$ Department of Human Sciences, Université du Québec à Trois-Rivières, Trois-Rivières, Canada.

${ }^{2}$ Department of History, Université du Québec à Montréal, Montréal, Canada.

${ }^{3}$ ImmunoConcept, UMR5164, CNRS, University of Bordeaux, Bordeaux, France.

${ }^{4}$ ImmunoConcept, UMR5164, CNRS, University of Bordeaux, Bordeaux, France.
} 
usual division between analytic and continental philosophy was in fact overstated. Some authors have applied text mining and computational topic-modeling algorithms to identify the historical evolution of key research topics in major philosophy of science journals (Malaterre et. al. 2019; Malaterre et. al. 2020). Others have used co-citation analysis to identify the set of central journals defining the field of philosophy of science (Wray 2010), the publications and authors that have had the most influence in the fields of philosophy of science (Wray and Bornmann 2015) and analytical philosophy (Petrovich and Buonomo 2018), as well as the representative topics of the discipline of philosophy (Healy 2013). Finally, other authors have applied bibliometric methods to study the relationship between philosophy of science and other fields or disciplines. Weingart (2014) used co-citation networks and bibliographic coupling to analyze the relationship between philosophy of science and history of science. Kreutzman (2001) used author co-citation analysis to study the relationship between philosophy of science and epistomology, while McLevey et. al. (2018) developed exponential random graph models to assess the effect that publishing in science journals has on the accumulation of symbolic capital inside the field of philosophy of science. Building on these studies, our paper aims, using citation analysis and citation networks, at assessing the changing visibility of philosophy of science in other fields of the natural sciences, engineering and mathematics (STEM) and the social sciences and humanities ( $\mathrm{SSH}$ ) over the last four decades.

Whether philosophy of science is, should be, or could be, useful to science and/or influences, should influence, or could influence science is a longstanding debate that has been recently reignited by philosophers of science as well as scientists (e.g. Pernu 2008; Pigliucci 2008; Rovelli 2018; Laplane et. al. 2019; De Haro 2020; Boniolo and Campaner 2020). Advocates of a wider diffusion of ideas and tools developped in philosophy of science, and of a tighter relationship between philosophy of science and the sciences, have mainly relied on individual examples of philosophers of science who have made significant philosophical contributions to understanding and resolving scientific problems, clarifying scientific concepts or critiquing scientific assumptions (Laplane et al. 2019). However, up to now, there are few empirical analyses that have assessed, on a larger scale, the extent to which the knowledge produced inside the field of philosophy of science has been actually used, or at least referred to, in science (Pradeu et al., submitted). This paper sheds light on 
this issue from a broader and more quantitative perspective, by measuring the visibility of philosophy of science papers in the sciences, through citations made to philosophy of science journals by STEM as well SSH disciplines. Explored at the three levels of disciplines, journals and authors, this quantitative analysis allows us to unveil several features of the relationship and interface between philosophy of science and a large and diversified array of disciplines.

In this paper, visibility is defined through the citations that the field of philosophy of science, its journals and its authors, has received from other sciences over the last four decades. We use the term "visibility" of philosophy of science in the sciences, rather than "influence" or "impact", because "visibility" describes in a more neutral and accurate way the very fact of being cited. Indeed, a philosopher doesn't need to be formally cited by authors from other sciences to influence them. For instance, although Einstein acknowledged the influence that David Hume and Ernst Mach's philosophy had on his theory of special relativity (Norton 2010), this influence did not translate into formal citations from his physics papers to Hume's and Mach's philosophical works. Another form of implicit scientific acknowledgement was underscored by sociologist Robert K. Merton, who identified the phenomenon of "obliteration by incorporation", according to which classic sources, although considered foundational, stop being cited (e.g., Galileo, Newton, Einstein) as they become taken for granted in a given scientific field (Merton 1988).

While influence doesn't necessarily translate into visibility, on the opposite, visibility does not necessarily mean influence. Indeed, as noted by MacRoberts and MacRoberts (1986, p. 167), "the mere presence of a reference is not a marker of influence, nor is the absence of a reference evidence that it is uninfluential". In that respect, Moravscik and Murugesan (1975) opposed "organic" and "perfunctory" citations, to establish the difference between citations that are "truly needed for the understanding of the referring paper" and express a genuine influence, and citations that are "mainly an acknowledgment that some other work in the same general area has been performed" (Moravscik and Murugesan 1975, p. 8). Since it is not the purpose of this paper to qualitatively evaluate the nature of citations made to philosophy of science by other disciplines, we refer to 
citations made to philosophy of science articles, journals and authors outside the field of philosophy of science as the visibility of philosophy of science in other sciences. We are here interested in the visibility of philosophy of science works in science at a global level, and propose a macroscopic analysis of the links between the discipline of philosophy of science and other scientific disciplines like biology, physics, mathematics, etc. Despite the existence of perfunctory citations, it remains that the act of citing a paper provides a reliable proxy for evaluating the degree of symbolic recognition that disciplines, journals and authors receive in the reward system of science (Merton 1973), as has been already documented in many sociology of science and bibliometric studies (Cole and Cole 1967; Garfield 1972; Price 1976; Merton 1988, Gingras 2016).

Analyzing citation flows between disciplines and citation networks contribute to our understanding of the structure of relationships, at a macro level, that philosophy of science maintains with other disciplines. Using quantitative bibliometric methods helps answer questions such as: what is the degree of openness of various disciplines to the specialized knowledge produced in philosophy of science? Which STEM and SSH fields and journals have privileged ties with philosophy of science? What are the characteristics, in terms of citation and publication patterns, of philosophy of science authors who get their philosophy of science papers cited outside their field? All these questions could, of course, be explored through qualitative inquiries and interviews on the influence of specific authors, topics or subfields of philosophy of science on other disciplines, but these inquiries could only offer a very limited portrait of the global structure of the multiple relationships that links philosophy of science to STEM and SSH disciplines. The global structure of those links can only be made visible by using tools developed in bibliometrics over the last forty years (Price 1963). In this paper, we have deliberately stuck to a descriptive stance, as our aim is first to replace hypothetical or fantasized views - that either exaggerate or downplay the visibility of philosophy of science in the sciences - with empirically validated data of the kind of relations they really entertain. In a complementary paper (Pradeu et al. submitted), we will try to characterize the precise philosophical content of the papers that happen to be much cited by scientists. 


\section{Bibliometric definition of the field of "philosophy of science"}

In order to obtain a representative landscape of the field of philosophy of science, we have selected 17 major philosophy of science journals included in the Clarivate Analytics Web of Science (WoS) database, one of the most commonly used in bibliometric studies, which also contains data on thousands of journals in all STEM and SSH disciplines. That same database also gives us all the citations to the papers published in the selected philosophy of science journals coming from journals in the STEM and SSH disciplines between 1980 and 2018. The WoS includes the Science Citations Index Expanded, the Social Sciences Citation Index, and the Arts and Humanities Citation Index. The disciplinary classification of journals used in this paper is that of the U.S. National Science Foundation ${ }^{5}$. This classification has the advantage of categorizing each journal into one single discipline, which avoids double counting and attributing citations made by a given journal to several disciplines. While philosophy of science is not formally defined in this classification as a single field or specialty of philosophy, we consider our list of 17 major philosophy of science journals as representative of the field, because they obviously include all the journals that most philosophers of science recognize as central in that domain. These journals are: Philosophy of Science, The British Journal for the Philosophy of Science, Synthese, Studies in History and Philosophy of Science (and its offsprings Part A, B, and C from 1998 onward), Erkenntnis, European Journal for the Philosophy of Science, International Studies in the Philosophy of Science, Journal for General Philosophy of Science, Foundations of Science, Hyle, History and Philosophy of the Life Sciences, Biology \& Philosophy, Theoretical Medicine and Bioethics, Journal of Medicine and Philosophy, Medicine Health Care and Philosophy. In addition to including the most central journals in philosophy of science (Wray 2010), this list of 17 journals covers large areas of philosophy of science, where researchers are the more active, such as philosophy of biology, philosophy of physics, and philosophy of medicine which is well represented with three journals.

\footnotetext{
${ }^{5}$ https://www.nsf.gov/statistics/nsf13327/pdf/tabb1.pdf
} 
Of course, philosophy of science articles are sometimes also published in more generalist philosophy journals, such as The Journal of Philosophy or Nous, and most importantly in philosophy of science books and edited volumes. In this study, citations made to philosophy of science books and book chapters are not included in our sampling, since this would have required to identify beforehand and manually all philosophy of science books that have been published in the last several decades - an obviously impossible task. However, given that our aim is not to construct a list of "most cited" people but to analyze the global links between disciplines, our selected list of 17 central philosophy of science journals allows us to define a representative community of authors in that field. Although citations made to philosophy of science books and book chapters are not counted, the several thousand articles contained in our list of 17 central philosophy of science journals, which are cited over a period of 40 years, provide us with a very strong statistical sample to determine the general structure of citation flows from STEM and SSH disciplines to philosophy of science as a discipline. Given that books are still important in philosophy, one could also argue that we should take into account citations coming from books and not only from journal articles. However, we have shown elsewhere that such an inquiry does not change substantially the general pattern observed through the lens of academic journals (Gingras and Khelfaoui 2019). The basic reason is that it would be very unlikely that a prominent or visible philosopher of science who would be cited for influential monographs or for papers he or she has published in general philosophy journals would not also have published papers in philosophy of science journals, and thus be cited for these papers. For all these reasons, we are confident that our list of 17 major philosophy of science journals provides a very representative, though not exhaustive, sample of the academic production in that field.

We assess the visibility of philosophy of science, that is of all authors who did publish in the selected journals regardless of their backgrounds and affiliations, in the other scientific fields at three levels: disciplines, journals and authors. At the discipline level, we analyze citation flows from STEM and SSH disciplines to the field of philosophy of science, as defined by our list of 17 journals. More precisely, we count the references made, between 1980 and 2018, by all disciplines to each of the 17 philosophy of science journals. The results obtained in this part of the paper allow us to determine which STEM and SSH 
disciplines are the most likely to cite philosophy of science, since we don't expect the external visibility of philosophy of science to be evenly distributed amongst all disciplines. In addition to establishing the degree of openess of STEM and SSH disciplines to philosophy of science, the results also allow us to define its level of insularity, that is, the degree to which a field is self-referencing. Total citations to philosophy of science from other disciplines are then calculated for each decade of the 1980-2018 period, in order to observe possible variations over time. Finally, in order to establish if the levels of insularity and visibility observed for philosophy of science are low, normal or high, we compare the results with those obtained for the the remaining field of general philosophy, as well as those obtained for the field of science studies, which shares a similar interest in science as philosophy of science, but from sociological and historical perspectives.

From the discipline macro level, we move a step further to analyze the visibility of philosophy of science in other sciences at the journal level. We do this by ranking the top10 journals of each the STEM and SSH disciplines that cite the most philosophy of science journals and the top- 5 philosophy of science journals cited by these disciplines. We thus focus on the journals that cite philosophy of science the most, though these journals are not necessairly the ones that are themselves the most cited in their own scientific discipline (as a way of illustration, in biology, these ten journals are, in the recent period: Acta Biotheoretica, Journal of Theoretical Biology, Evolutionary Biology, Theory in Biosciences, Cladistics, Evolution, Biosystems, Journal of Experimental Zoology Part B, Biology Direct, and the Journal of Evolutionary Biology). While citation flows at the discipline level help us identify the STEM and SSH disciplines that cite the most philosophy of science, citation analysis at the journal level provides us with a more precise idea of the subfields of these discipline that have a particular affinity with philosophy of science. For instance, in biology, we expect, for obvious reasons, that journals in the subfield of evolutionary biology are more likely to cite philosophy of biology articles than journals in the subfield of biochemistry or oceanography. Similarly, in physics, we expect theoretical physics journals to be more likely to cite philosophy of modern physics articles than applied physics or optics journals. The list of top- 10 citing and top- 5 cited journals is also established for each decade of the 1980-2018 period, in order to observe possible variations over time. Similarly, a time analysis of the top-5 cited philosophy of science 
journals in each citing discipline makes it possible to observe variations over time in the philosophy of science journals that are of interest to other disciplines. For instance, if biology consistently cites philosophy of science journals, we expect that Biology \& Philosophy, as well as Studies in History and Philosophy of Biological and Biomedical Sciences will appear amongst the most visible philosophy of science journals in these disciplines. We also expect that, with the rise of ethical issues in the contemporary practice of medicine and biology, medicine and biomedical sciences will show over time a more pronounced interest for medical ethics and bioethics journals, such as Theoretical Medicine and Bioethics.

Journal rankings only provide a limited description of citation flows from STEM and SSH journals to philosophy of science journals, since they only give, for each citing discipline, information on the top- 10 citing and top- 5 cited journals. In complement to these rankings, we generated citation networks, using the open-source visualization software Gephi (Cherven 2013), to provide a more comprehensive picture of the citation relationship between philosophy of science journals and all other STEM and SSH journals. Citation networks are represented by nodes connected by edges. Each node represents either a citing journal or a philosophy of science cited journal. Nodes representing philosophy of science journals are colored in red, in order to distinguish them from other citing journals. Edges represent citations from STEM or SSH journals to philosophy of science journals. The more a STEM or SSH journal cites a given philosophy of science journal, the thicker will be the edge that connects them. The more a philosophy of science journal receives citations from different STEM or SSH journals, the more central its position will be in the network, and the larger the size of its node will be. We show three different networks that represent citation flows from STEM journals, social science journals, and humanities journals to our 17 philosophy of science journals. In order to facilitate the visibility of the main nodes of the network, we only show links between journals with at least 15 citations between 1980 and 2018. One of the main features of the Gephi software is its use of the Louvain community detection algorithm to identify coherent clusters (identified by nodes of the same color) within a larger network (Blondel et al. 2008). In our case, these clusters represent different communities of journals that share the particularity of citing the same philosophy of science journals. In this regard, citation networks do not only provide a more 
comprehensive picture of the journals who cite philosophy of science, but also allow to define sub-communities of citing journals, which might be composed of different STEM, social science or humanities disciplines.

From the journal level, we then move to the author level. We define a list of authors who have contributed as first authors at least one article in one of the 17 philosophy of science journals and have received for their articles at least 20 citations from STEM journals or 20 citations from philosophy of science journals, between 1980 and 2018 (we apply the 20 citations threshold over the period to keep the number of authors in the network manageable). While the choice of counting citations to first co-authors is dictated by technical constraints, it remains that $86 \%$ of the articles published in our sample of 17 philosophy of science journals are single authored. Moreover, it is very unlikely that any important philosophy of science author would be cited solely for articles where he or she appears as second or third co-author. Thus, we are confident that by counting citations only to first co-authors, and by using a low citation threshold of 20 citations over a 30 years period, we adequatley capture the global visibility of philosophers of science. Through this method, we can define three different communities of authors: 1) authors of philosophy of science articles who remain mostly cited, and therefore visible, in the field of philosophy of science; 2) authors who get cited in both philosophy of science and STEM disciplines; and 3) authors who get mostly cited, and are thus mainly visible, in STEM disciplines. We then use the citation and publication patterns of these authors to identify the characteristics that seem to allow their philosophy of science articles to transcend the boundaries of their field and gain visibility in science disciplines.

\section{Which scientific disciplines cite philosophy of science journals?}

We start by assessing the visibility of philosophy of science in other sciences at the discipline level. In Figure 1, an alluvial chart provides the distribution of citations from different STEM and SSH disciplines to philosophy of science, between 1980 and 2018. It shows that $30.2 \%$ of all citations to philosophy of science come from that field, and that $19.7 \%$ come from the rest of philosophy. Overall, $49.9 \%$ of the citations made to philosophy of science journals come from philosophy, broadly defined (i.e., including philosophy of science). Our results confirm McLevey's et. al. finding that "roughly half 
of the citations to articles in (philosophy of science) journals come from journals in different disciplines" (McLevey et. al., 2018). With 28.8\% of citations, SSH is the second grand disciplinary field citing philosophy of science. Psychology, health and science studies are the three SSH discplines that cite the most philosophy of science journals. With $21.3 \%$ of citations, STEM is the third grand disciplinary field citing philosophy of science. As in SSH disciplines, citations to philosophy of science are not evenly distributed among STEM disciplines. Indeed, clinical medicine, biology and physics are the three disciplines where philosophy of science is the most visible, while it is almost invisible in a field such as chemistry, or earth and atmospheric sciences. These differences might be explained by the fact that those disciplines tend to be more applied and less fundamental. The fact that some sub-specialties of philosophy of science, like philosophy of chemistry or enginering, developed only recently may also contribute to explain that low level of visibility.

Another part of the explanation for the tendency of some scientists to cite philosophy of science could come from some recent evolutions in the field of philosophy of science. These evolutions might include:

i) an increasing focus on philosophy of special sciences (philosophy of biology, physics, and so on) rather than general philosophy of science (Mizrahi 2020);

ii) the emergence of "philosophy of science in practice", an approach "dedicated to fostering the pursuit of a philosophy of science that considers theory, practice and the world simultaneously, and never in isolation from each other" (Ankeny et al. 2011);

iii) an emphasis, by an increasing number of philosophers of science, on advancing science rather than simply discussing science. We have proposed an in-depth analysis of this latest aspect in another paper (Pradeu et al. submitted). We called it "philosophy in science", and defined it by the use of philosophy as a toolbox to help solve scientific problems. "Philosophy in science" is particularly prone to have a higher visibility in science, because it tends to raise the exact same questions that scientists themselves are trying to solve in their daily practice. 
Figure 1 - Distribution of citations to philosophy of science journals coming from other disciplines between 1980 and 2018 (\%)

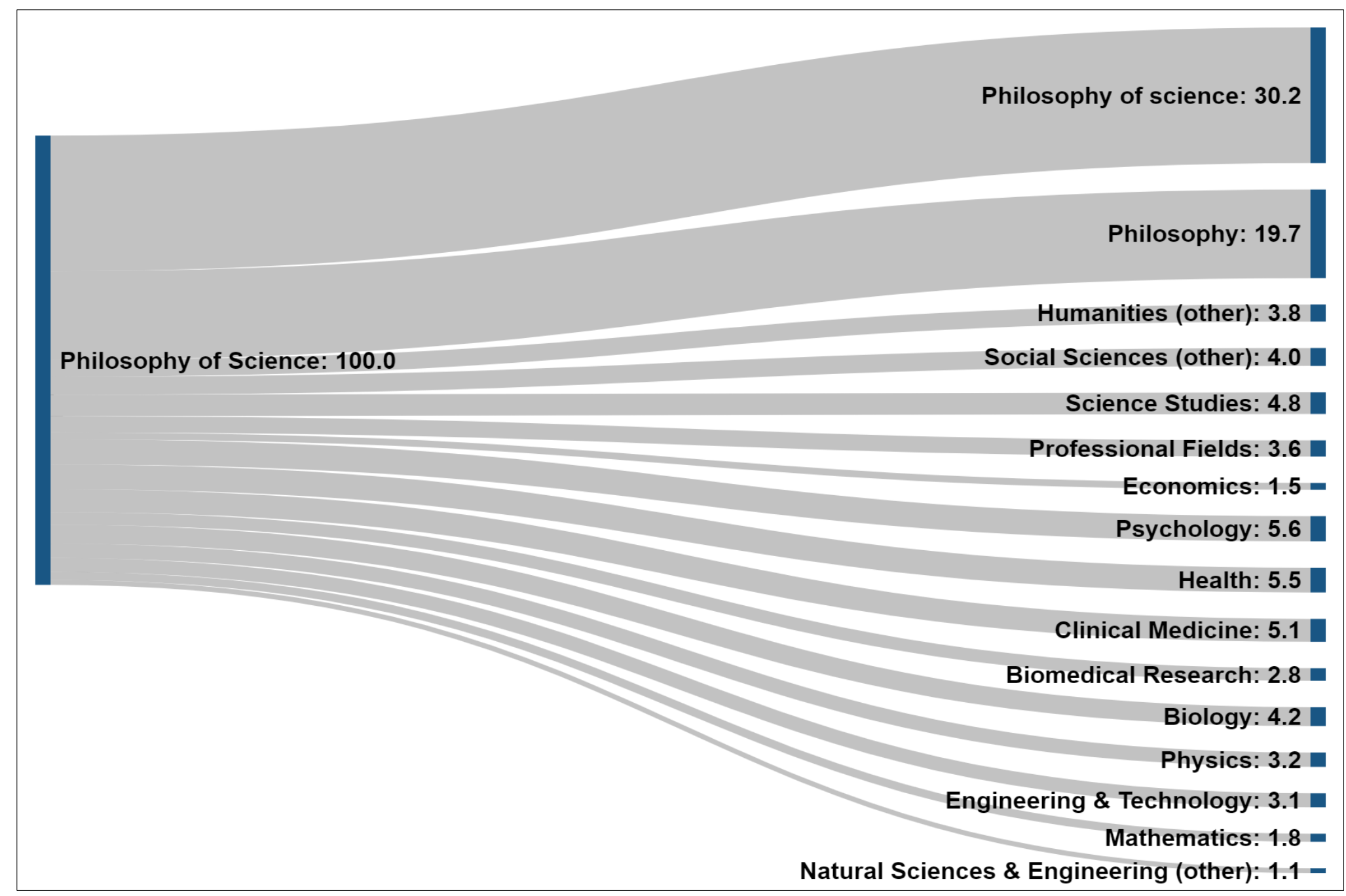


As shown in Table 1, when compared to philosophy of science, the rest of the field of philosophy is significantly more self-referencing, since $57.1 \%$ of citations to philosophy are internal to this field (excluding philosophy of science), while $9.4 \%$ of citations to philosophy are from philosophy of science journals. This difference between philosophy and philosophy of science is mainly attributable to an effect of field size. Indeed, since the field of philosophy includes significantly more journals and researchers than the subfield of philosophy of science, it is not surprising that many more citations are generated within the field of philosophy, since the potential number of citing items is larger. While its share of citations from SSH disciplines is equivalent to that of philosophy of science $(27.5 \%)$, the rest of the field of philosophy receives, as could be expected, much less citations from STEM disciplines, with only $5.9 \%$, comparatively to $21.3 \%$ for philosophy of science. When compared to the field of science studies, which also has an interest in science but from a more sociological and historical perspective, philosophy of science has a similar visibility in STEM disciplines $(21.3 \%$ for philosophy of science vs $18.5 \%$ for science studies). Both fields also have a similar level of insularity or percentage of self references (30.2\% philosophy of science vs $29.2 \%$ for science studies).

Table 1 - Distribution of citations made to philosophy, philosophy of science and science studies journals from other disciplines

\begin{tabular}{|c|c|c|c|c|}
\hline $\begin{array}{c}\text { Research } \\
\text { fields }\end{array}$ & $\begin{array}{c}\text { Philosophy of } \\
\text { science }\end{array}$ & Philosophy & $\begin{array}{c}\text { Other Social } \\
\text { sciences and } \\
\text { humanities }\end{array}$ & $\begin{array}{c}\text { Natural } \\
\text { Sciences and } \\
\text { Engineering }\end{array}$ \\
\hline $\begin{array}{c}\text { Philosophy of } \\
\text { science }\end{array}$ & 30.2 & 19.7 & 28.8 & 21.3 \\
\hline Philosophy & 9.4 & 57.1 & 27.5 & 5.9 \\
\hline $\begin{array}{c}\text { Science } \\
\text { studies }\end{array}$ & 2.7 & 1.4 & $\begin{array}{c}77.4 \\
(29.2 \text { in science } \\
\text { studies })\end{array}$ & 18.5 \\
\hline
\end{tabular}

Table 2 provides the distribution of citations to philosophy of science made by other disciplines, for each decade of the 1980-2018 period. The breakdown by decade makes visible the variations through time in the share of citations made by each major discipline to philosophy of science. The level of self-referencing of philosophy of science has increased from $26.9 \%$ to $31.8 \%$ between 1980 and 2018 , while the share of citations received from philosophy has decreased from 25.9 to $19.9 \%$ during the same period. This 
result suggests that the specialty of philosophy of science has grown in size, including more journals and more researchers, and become more autonomous from the rest of philosophy. The disciplines of health and clinical medicine are those where philosophy of science has increased its visibility the most as compared to other STEM and SSH fields (from 1.7 to $6.1 \%$ in health, and from 2.8 to $5.2 \%$ in medicine). This can be explained by the rise of ethics-related issues in these two fields, reflections that generate more citations to publications on medical ethics in the field of philosophy of science. Other disciplines where the visibility of philosophy of science has not changed significantly over time are biology, physics, mathematics, engineering, professional fields and science studies. It is also interesting to observe that the visibility of philosophy of science has experienced an important decline in psychology (from 8.1 to $4.8 \%$ ), economics (from 2.8 to $1.2 \%$ ), and language and linguistics (from 2.5 to 1.1\%). However, this decline might only be apparent and biased by the fact that three interdisciplinary journals with a huge philosophical focus, Philosophy and Psychology, Economics and Philosophy, Linguistics and Philosophy are classified in the WoS database as being part of these three disciplines and not as philosophy journals. When citations to these three journals are considered as citations to philosophy of science journals, the visibility of philosophy of science in psychology declines from 8.1 to $5.7 \%$, in economics from $2.9 \%$ to $1.7 \%$, and in language and linguistics from $5.0 \%$ to $4.6 \%$. Thus, while the decline of the philosophy of science in psychology and economic is confirmed, the inclusion of Linguistics and Philosophy in the list of philosophy of science journals shows that the visibility of philosophy of science has remained stable over time in the discipline of language of linguistics.

Table 2 - Distribution of citations to philosophy of science journals made by STEM and SSH disciplines, percentage by decade

\begin{tabular}{|l|c|c|c|c|}
\hline Discipline & $\mathbf{1 9 8 0 - 1 9 8 9}$ & $\mathbf{1 9 9 0 - 1 9 9 9}$ & $\mathbf{2 0 0 0 - 2 0 0 9}$ & $\mathbf{2 0 1 0 - 2 0 1 8}$ \\
\hline Philosophy of Science & 26.9 & 27.9 & 29.2 & 31.8 \\
\hline Philosophy & 25.9 & 19.7 & 17.2 & 19.9 \\
\hline Biology & 4.2 & 4.6 & 5.5 & 3.4 \\
\hline Physics & 2.3 & 2.9 & 3.4 & 3.3 \\
\hline $\begin{array}{l}\text { Engineering \& } \\
\text { Technology }\end{array}$ & 2.0 & 4.1 & 3.7 & 2.8 \\
\hline Mathematics & 1.5 & 1.2 & 1.5 & 2.0 \\
\hline Biomedical Research & 1.2 & 1.7 & 2.6 & 3.3 \\
\hline
\end{tabular}




\begin{tabular}{|l|c|c|c|c|}
\hline Medicine & 2.8 & 4.6 & 6.3 & 5.2 \\
\hline Psychology & 8.1 & 7.6 & 5.6 & 4.8 \\
\hline Health & 1.7 & 4.5 & 6.7 & 6.1 \\
\hline Professional Fields & 3.7 & 4.5 & 3.3 & 3.4 \\
\hline Science Studies & 4.3 & 3.6 & 4.4 & 4.6 \\
\hline Economics & 2.8 & 2.2 & 1.5 & 1.2 \\
\hline $\begin{array}{l}\text { Language \& } \\
\text { Linguistics }\end{array}$ & 2.5 & 1.7 & 1.5 & 1.1 \\
\hline $\begin{array}{l}\text { Other STEM or SSH } \\
\text { disciplines }\end{array}$ & 11.1 & 9.2 & 7.6 & 7.1 \\
\hline Total & 100.0 & 100.0 & 100.0 & 100.0 \\
\hline
\end{tabular}

\section{Which scientific journals cite philosophy of science journals?}

It is well known that the distribution of citations within a set of journals is not homogeneous and rather follows in general a power law such that a minority of journals account for the large majority of the citations received. It is thus useful to observe the level of concentration of citations among the top-ten citing journals for each citing discipline. This measure gives an indication of the degree of dispersion of citations made to philosophy of science among the many journals of each citing discipline. The more citations are concentrated in the top-10 citing journals, the more the interest of that discipline in philosophy of science is restricted to a limited number of journals, which may indicate that there exists a sub-community of that discipline with a special interest for those philosophical questions about their science. As shown in Table 3, a first general observation is that, between 1980 and 2018, the concentration of citations to philosophy of science has declined in all other disciplines' top-10 citing journals, except for mathematics which, after a significant decline in concentration (from 68.2 to $50.5 \%$ between 1980 and 2009), has increased to its initial level, due to an important surge in citations to philosophy of science journals in the Review of Symbolic Logic. Overall, philosophy of science has enjoyed a larger spread and visibility among science journals of disciplines other than mathematics over the last four decades. Disciplines where citations to philosophy of science journals have dispersed in a larger number of journals are science studies, physics, engineering and technology, health, medicine, and economics. Disciplines where concentration of citations has not changed substantially are psychology, language and linguistics, and biology. 
Table 3 - Proportion of citations to philosophy of science coming from top-10 citing journals, by discipline

\begin{tabular}{|l|c|c|c|c|}
\hline Discipline & $\mathbf{1 9 8 0 - 1 9 8 9}$ & $\mathbf{1 9 9 0 - 1 9 9 9}$ & $\mathbf{2 0 0 0 - 2 0 0 9}$ & $\mathbf{2 0 1 0 - 2 0 1 8}$ \\
\hline Philosophy & 43.1 & 46.8 & 40.8 & 31.3 \\
\hline Biology & 40.3 & 35.9 & 39.9 & 30.6 \\
\hline Physics & 79.4 & 77.6 & 55.0 & 56.6 \\
\hline Engineering \& Technology & 64.7 & 57.9 & 59.5 & 47.0 \\
\hline Mathematics & 68.2 & 54.5 & 50.5 & 69.3 \\
\hline Clinical Medicine & 38.4 & 20.6 & 14.9 & 20.6 \\
\hline Health & 63.3 & 55.8 & 52.6 & 44.1 \\
\hline Psychology & 52.5 & 47.4 & 48.5 & 48.6 \\
\hline Science Studies & 88.2 & 85.2 & 70.9 & 60.5 \\
\hline Economics & 71.7 & 61.7 & 62.0 & 53.7 \\
\hline Language \& Linguistics & 73.1 & 81.1 & 80.1 & 68.6 \\
\hline
\end{tabular}

In Appendix A, the visibility of philosophy of science is further analyzed by looking, for each discipline and decade, at the top-10 journals citing philosophy of science, as well as the top-5 cited philosophy of science journals. In some STEM disciplines, the top-10 journals citing philosophy of science share the particularity of focusing on the theoretical foundations and principles of their discipline and of hosting scientific papers of a conceptual and philosophical nature. This is, for instance, the case of biology which counts amongst its top-10 citing journals Acta Biotheoretica, the Journal of Theoretical Biology, and Theory in Biosciences. Journals focusing on the topics of evolution (Evolution, Evolutionary Biology), biological systematics (Systematics Biology, Systematics Zoology, Systematics Botany), and cladistics (Cladistics) are also amongst the top biology journals citing consistently philosophy of science across the whole studied period. Unsurprisingly, the most popular philosophy of science journal cited by the discipline of biology is Biology \& Philosophy; it is followed by Philosophy of Science, The British Journal for the Philosophy of Science, Studies in History and Philosophy of Science (before 2000), and Studies in History and Philosophy of Science - Part C (which has an obvious focus on biology), also remain consistently in the top-5 cited philosophy of science journals over the whole analyzed period.

In the case of physics, the top-10 journals citing philosophy of science are also interested in the theoretical and conceptual foundations of the discipline. Over the four decades, Foundations of Physics remains the top journal citing philosophy of science, 
followed by International Journal of Theoretical Physics. American Journal of Physics also consistently cites philosophy of science, which is not surprising, since this journal has a strong focus on methods and pedagogical issues in the teaching of physics, which can benefit from philosophical insights for the transmission of knowledge in this discipline. Some specialties of physics seem also more likely to cite philosophy of science journals than others. It is the case of particle physics, atomic and molecular physics (Physical Review D, Physical Review A), which might cite philosophy of quantum physics articles, gravitation (Classical and Quantum Gravity), and mathematical physics (Philosophical Transactions of the Royal Society - Part A, Journal of Mathematical Physics, Physics Journal A). Between 1980 and 1999, Philosophy of Science is the most cited philosophy of science journal by physics journals, but it is replaced in the 2000-2018 period by Studies in History and Philosophy of Science - Part B, which has an exclusive focus on the history and philosophy of modern physics.

Citations to philosophy of science journals from the discipline of mathematics come from three main specialties: probability and statistics, logics, and applied mathematics. Between 1980 and 1999, mathematics journals citing philosophy of science are mainly focused on issues of statistical inference and probabilistic causality on the one hand (Annals of Statistics, American Journal of Statistical Inference), and logic on the other hand (Journal of Symbolic Logic, Annals of Pure and Applied Logic). While philosophy of science articles remain visible in logic journals between 2000 and 2018, mathematics applied to computer science and artificial intelligence (Fundamenta Informaticae, Annals of Mathematica and Artificial Intelligence) become much more open to philosophy of science during the same period. By contrast, between 2000 and 2018, statistics journals almost disappeared from the top-10 mathematics journals citing philosophy of science. In engineering and technology journals, citations to philosophy of science journals are mainly concentrated in the subfield of computer science, more particularly around the topics of fuzzy sets, artificial intelligence and cybernetics (Fuzzy Sets and Systems, Artificial Intelligence, Minds and Machines, Kybernetes). Synthese, followed by Philosophy of Science, is the most cited philosophy of science journals by both disciplines of mathematics and engineering and technology. This is not surprising since some subfields of these two disciplines share a similar interest in philosophy of science. 
Medicine and health share a common interest in ethical and bioethical issues raised by philosophy of science. The top-10 medicine journals citing philosophy of science journals cover a wide spectrum of medical specialties, ranging from biomedicine, internal medicine, epidemiology, pediatrics, geriatrics, critical care, psychiatry, to brain research. This disciplinary diversity confirms a result obtained in Table 3 that showed that, over the four analyzed decades, medicine has the lowest concentration of philosophy of science citations in its top-10 citing journals. In other words, as compared to other STEM and SSH disciplines, interest for philosophy of science in medicine is more widely spread across its different specialties. In the social sciences of health, citations to philosophy of science journals come mainly from medical ethics and nursing ethics journals (Medical Ethics, Bioethics, Nursing Ethics). The journal Social Science \& Medicine also cites highly philosophy of science journals, mainly for articles related to medical and social ethics. Unsurprisingly, three philosophy of science journals, with a large focus on ethics and bioethics, are the most cited by both medicine and health disciplines: Journal of Medicine and Philosophy, Medicine, Heath Care and Philosophy, and Theoretical Medicine and Bioethics.

In the field of psychology, the top-10 journals citing philosophy of science are mainly concentrated in the two subfields of behavioral science (Behavioral and Brain Sciences, Journal of Brain Behavior) and cognitive science (Cognition, Cognitive Science). Theoretical psychology journals, such as Theory in Psychology and New Ideas in Psychology, as well as interdisciplinary journals such as Frontiers in Psychology and Psychology and Philosophy (which is devoted to studying the links between psychology and philosophy) are also amongst these top-10 citing journals over the four decades analyzed here. The most cited philosophy of science journals in psychology are also the most central in the field of philosophy of science (Wray 2010): Philosophy of Science, The British Journal for the Philosophy of Science, and Synthese. Finally, in the field of science studies, philosophy of science articles are mainly cited by sociology of science and technology journals (Social Studies of Science, Science, Technology and Human Values), history of science (Isis, History of Science), and history of biology journals (Journal of the History of Biology, British Journal for the History of Science). The most cited philosophy of science journals in science studies is Studies in History and Philosophy of Science - Part 
$A$, which is not surprising since philosophy of science is closely linked with the field of science studies (including history of science), through the intermediate field of history and philosophy of science (HPS) (see Figure 1 in Weingart 2015, p. 208).

\section{Network of relations between journals}

The relationship between citing STEM and SSH journals and cited philosophy of science journals can be further explored through journal citation networks presented in figures 2, 3, and 4. Figure 2 shows the network of STEM citing journals and philosophy of science cited journals. The network displays four distinct citing communities which are colored in blue, green, red and purple. At the right of the network, the blue community represents STEM journals that cite philosophy of medicine journals, with Journal of Medicine and Philosophy being, by far, the most cited in this community. Unsurprisingly, STEM journals in the blue community belong exclusively to the discipline of medicine. The green community at the center of the network is mostly composed of biology journals (with a few other biomedical science journals) citing Biology \& Philosophy, then, to a lesser extent, Studies in History and Philosophy of Biological and Biomedical Sciences, and, marginally, History and Philosophy of the Life Sciences. The orange community at the left of the network is composed of physics journals that cite mainly Studies in History and Philosophy of Modern Physics, and to a lesser extent Studies in History and Philosophy of Science - Part A. The purple community at the top of the network is composed of mathematics and computer science journals first citing Synthese, and then Erkenntnis. Two philosophy of science journals stand at intermediate positions between different communities. The main one, Philosophy of Science, is cited by journals from the four communities and stands at the heart of the network, which reflects the variety of topics tackled by its articles and the centrality of this journal, not only in the field of philosophy of science, but also as seen from STEM journals citing philosophy of science. Slightly offcentered at the right of the network, The British Journal for the Philosophy of Science is cited by all communities except medicine. Finally, it is interesting to notice the intermediate position of two science journals in the network, PLoS One and Science. Their particular position reflects the fact that these journals, known for covering all scientific

disciplines, but focusing on bioscience and medicine (Milojevic, 2020), cite philosophy of 
science journals with a particular inclination for philosophy of biology and philosophy of medicine.

Figure 3 shows the network of citation between social science journals citing philosophy of science journals. The network is structured by three communities in blue, green and orange. The blue community at the right of the network is composed of social sciences of health journals citing philosophy of medicine journals. The green community, at the bottom left of the network, is composed of science studies journals. The top part of this community is structured around sociology and history of science journals mainly citing Studies in History and Philosophy of Science - Part A, while the bottom part, where history of medicine journals are more present, is structured around Studies in History and Philosophy of Biological and Biomedical Sciences, as well as History and Philosophy of the Life Sciences. It is interesting to notice the intermediate position held by Social History of Medicine, which cites both philosophy of life science journals (in the green community) and philosophy of medicine journals (in the blue community). Biology \& Philosophy and British Journal for Philosophy of Science are situated at the border of the science studies journals community, and the community in orange. The latter is populated by journals from various disciplines (economics, professional fields, sociology), but largely dominated by psychology journals, especially those specialized in behavior and cognition. This orange community is divided in two sub-communities, one structured around Synthese and the other around Philosophy of Science. As was the case in the previous network of STEM journals citing philosophy of science journals, Philosophy of Science also occupies a central position in the whole network of social sciences journals, being cited by journals from the three communities.

Figure 4 shows the network of relationships between humanities journals, featuring disciplines such as philosophy, history, and language and linguistics, citing philosophy of science journals. Four communities, in blue, green, orange and purple are visible. The most important community, in purple at the top left of the network, includes a majority of philosophy journals and is centered around Synthese, which is also the most cited journal in the whole network. Philosophy journals in the purple community also tend to cite British Journal for Philosophy of Science, Philosophy of Science and Erkenntnis. Another smaller community, in orange at the bottom left, is also composed of philosophy journals but is 
centered around Philosophy of Science, while also citing to a lesser extent philosophy of science journals that structure the purple community. The green community at the bottom of the network features mainly history of philosophy and history of ideas journals, centered around Studies in History and Philosophy of Science - Part A. Finally, the small blue community at the right of the network represents humanities journals, especially in religious studies and ethics, citing philosophy of medicine journals. 
Figure 2 - Network of STEM journals citing philosophy of science journals (1980-2018)

\begin{tabular}{|c|c|c|}
\hline \multicolumn{2}{|c|}{ 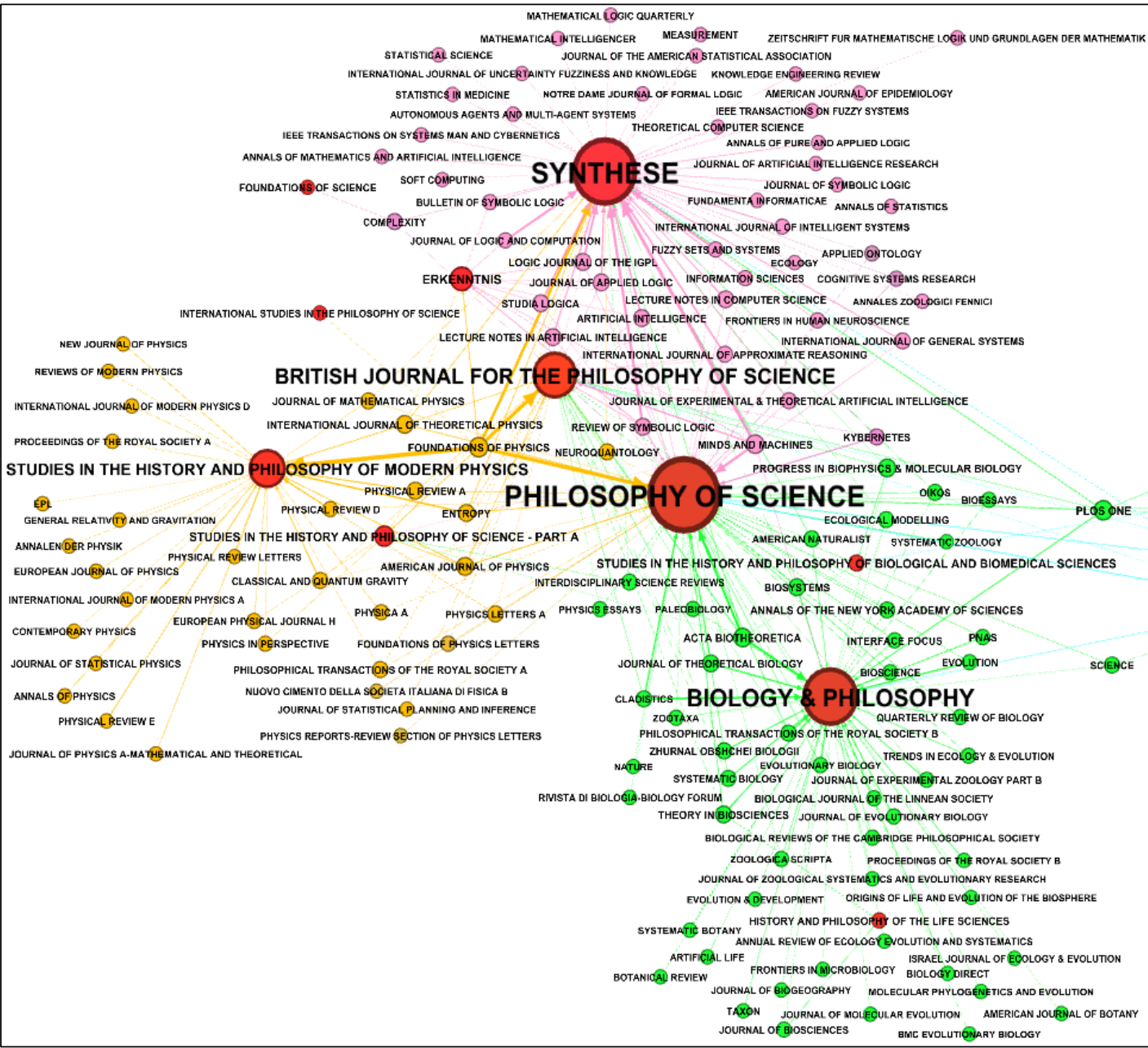 } & 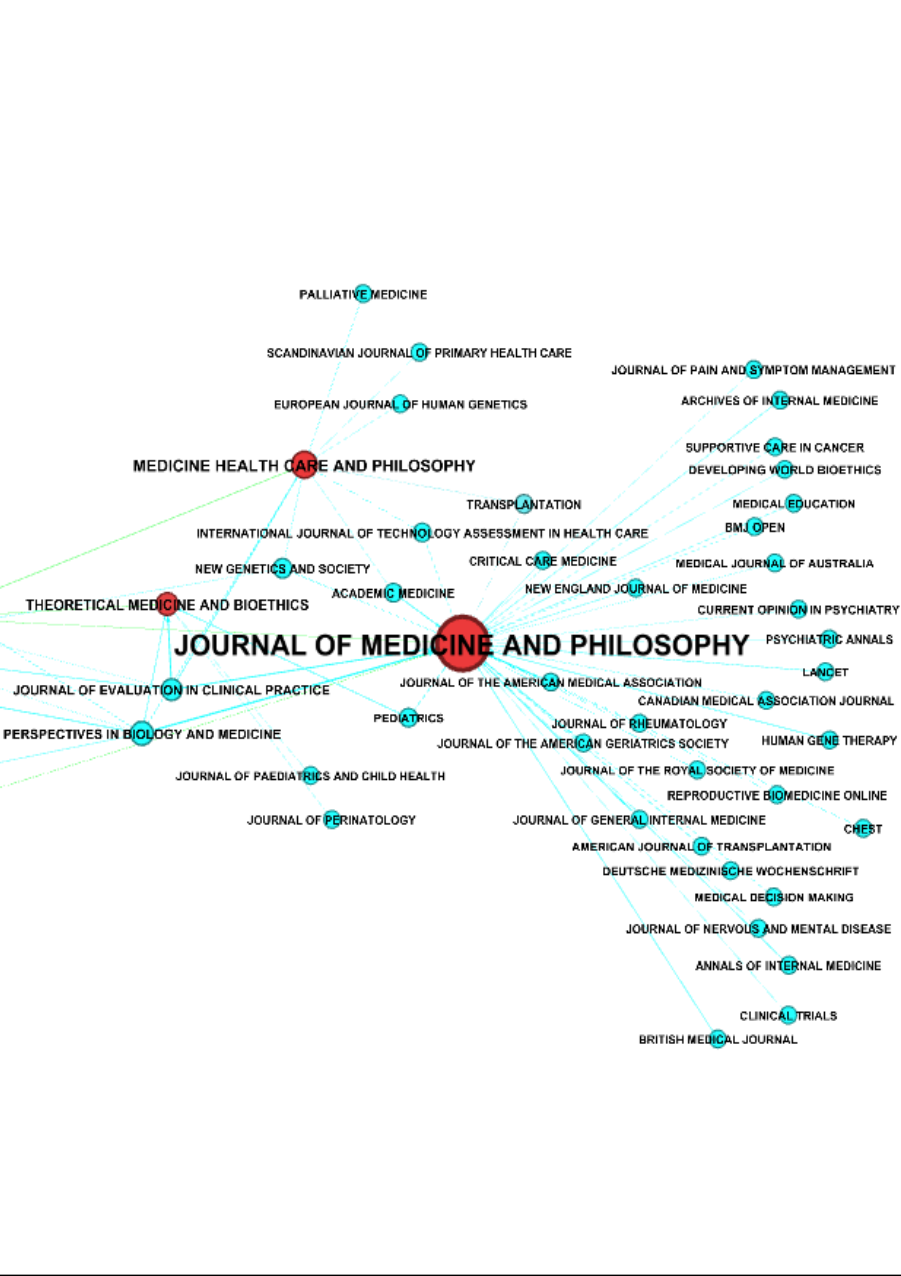 \\
\hline
\end{tabular}


Figure 3 - Network of Social Sciences journals citing philosophy of science journals (1980-2018)

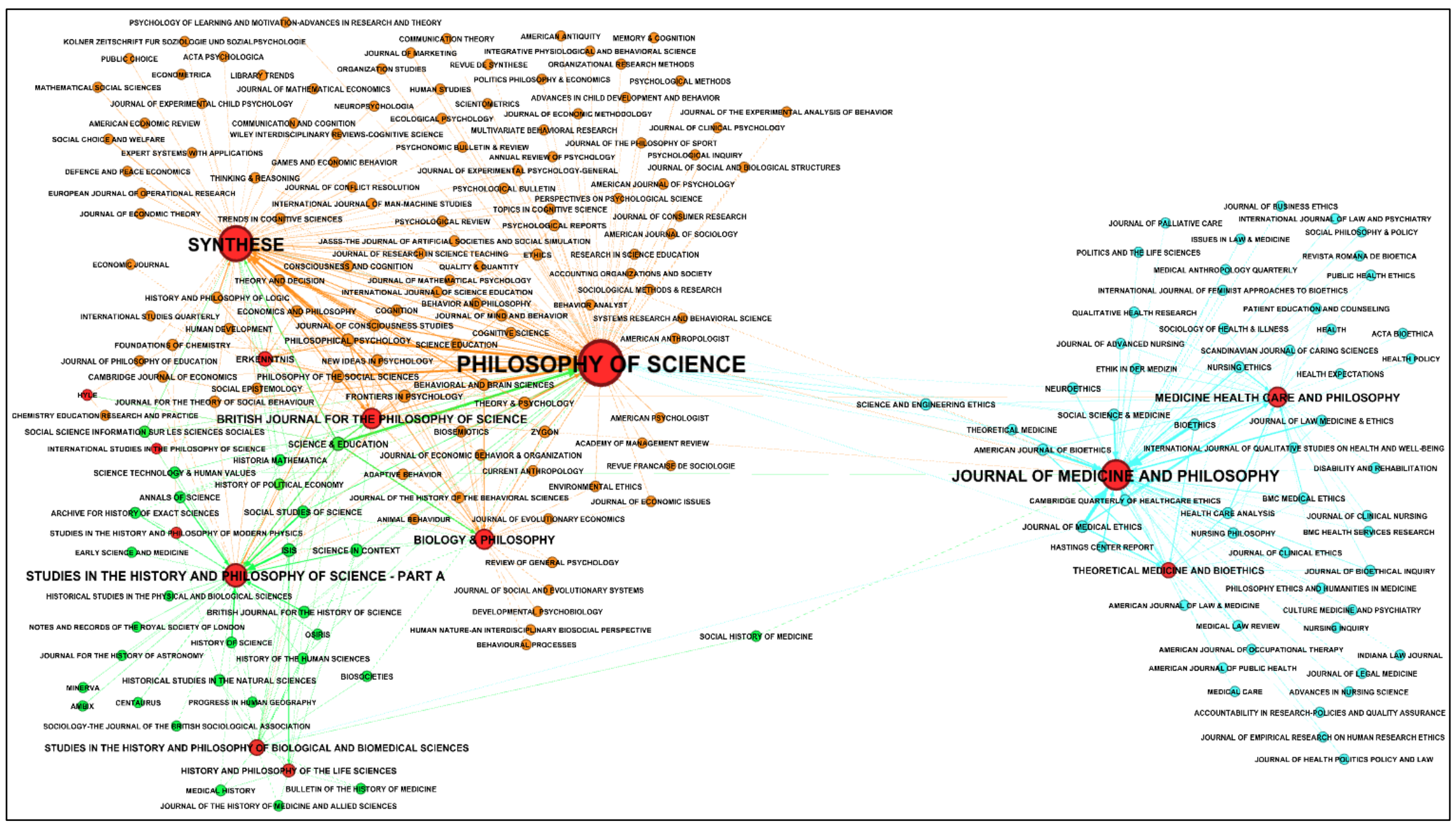


Figure 4 - Network of Humanities journals citing philosophy of science journals (1980-2018)

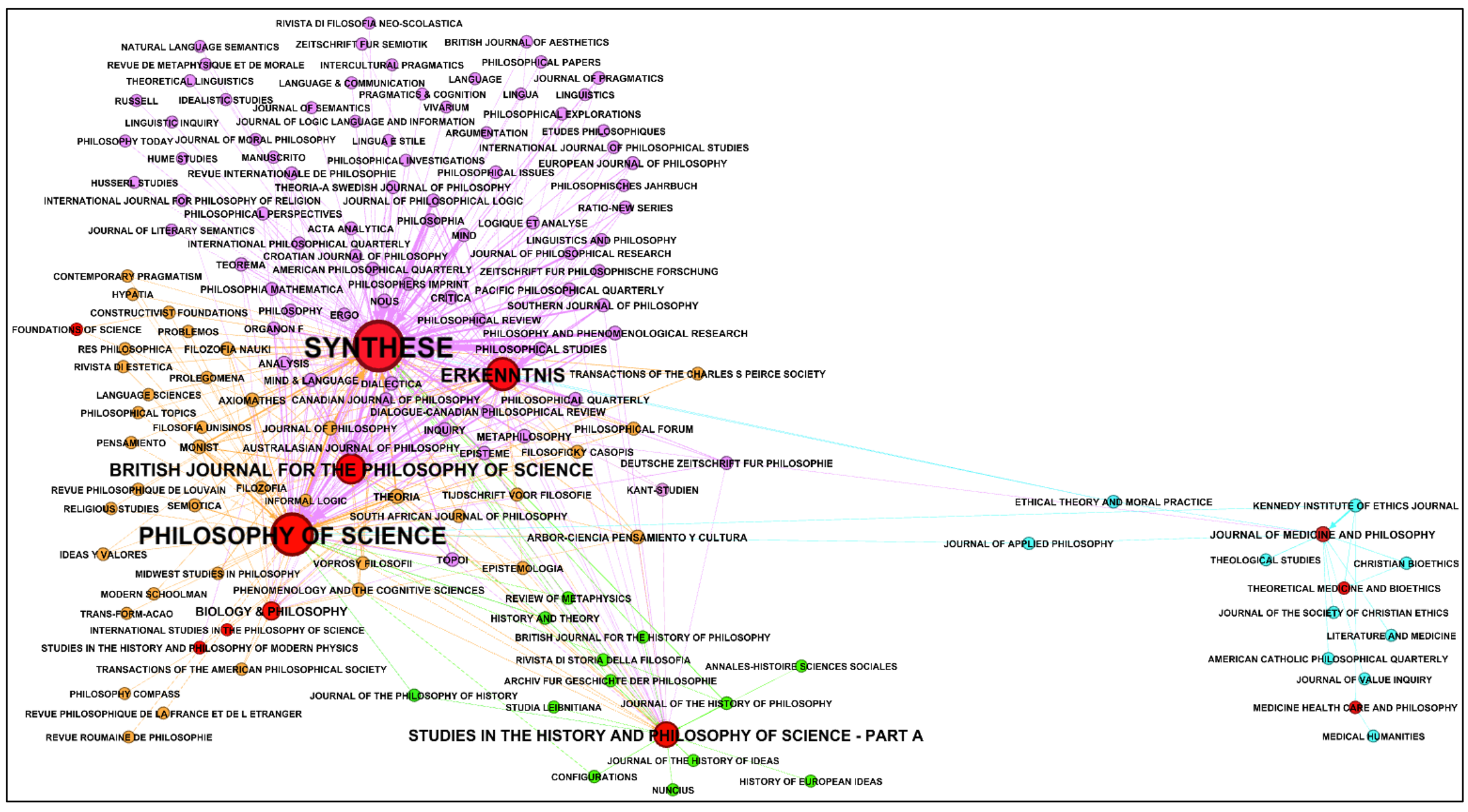




\section{The visibility of philosophers of science in other sciences}

Though disciplines have particular structural characteristics, they are of course composed of researchers with their own social characteristics and intellectual contributions to the field. We will now look at the last level of analysis, that of authors of the articles published in the 17 journals that for us are representative of the field of philosophy of science. Being interested in the links of that discipline to other scientific disciplines, and not in the internal dynamic of philosophy of science itself, we limit our focus on citations coming from STEM fields to authors who published in our set of philosophy of science journals. For this purpose, we construct a network that connects scientific disciplines to philosophers of science.

Figure 5 shows citations from STEM and philosophy of science fields (each represented by a single node) to authors who have published at least one paper as a first author in one of the 17 philosophy of science journals before 2018. To make the network legible, we show only links for authors having at least 20 citations from the STEM field or from philosophy of science in the 1980-2018 period. The more citations an author receives from the fields of STEM or philosophy of science, the thicker is the edge that connects that author's node to the discipline citing him or her. As shown in Figure 5, the network is strikingly structured by three distinct communities of authors. The community at the right of the network is composed of 297 authors who are mostly cited by philosophy of science journals, meaning that their articles do not transcend the boundary of their field. Authors featured in this community are in large majority philosophers of science, or philosophers who publish at least part of their works in philosophy of science journals. The two other communities are the most interesting to analyze, since they are composed of authors who get some of their philosophy of science articles cited not only in philosophy of science but also in STEM disciplines. Their work thus appears more visible to scientists than those of the first group.

The community at the left of the network represents authors of philosophy of science articles who are mainly cited by journals of STEM disciplines. A detailed analysis of the 169 author names composing this community shows that it mainly includes scientists who have published one or several articles in philosophy of science journals. These articles have mainly attracted the attention of other scientists, since they are largely cited by STEM 
journals. This is for example the case of computer scientists Joseph Goguen and Lotfi Zadeh, who have been abundantly cited by mathematicians and engineers for two paper on fuzzy logic they published in Synthese (Goguen 1969; Zadeh 1975). These citations to Zadeh and Goguen partly explain why Synthese is the most cited philosophy of science journal in the disciplines of mathematics and engineering and technology. Famous physicists Albert Einstein, Niels Bohr and Edwin Schrödinger, whose philosophy of science papers have been published in the 1930s and 1950s are still cited nowadays by physics journals. But most physicists that are cited in STEM journals for articles they published in philosophy of science journals are still active, including Mario Castagnino, Stephen Adler, Charles H. Bennett, Michele Campisi, and Diederick Aerts. Some prominent biologists have also published philosophy of science papers that are highly cited in STEM journals, such as Theodosius Dobzhansky, John Maynard Smith, Daniel Simberloff, Brian K. Hall, Richard Michod, and others. Scientists from different STEM disciplines are also present in this community, which is actually mainly populated by scientists, not professional philosophers of science. As shown in Table 4, 24.7\% of these authors are mainly active in the field of biology, followed by medicine, physics, mathematics and engineering. This result suggests that scientists from these STEM disciplines might also be the most likely to publish articles in philosophy of science journals. Bioethicists, mostly in medical ethics, form $12.9 \%$ of the community, while social scientists, mostly from the fields of psychology and science studies, only form $5.7 \%$ of the community. Interestingly, the community also includes $9.4 \%$ of philosophers mainly active in subfields of philosophy other than philosophy of science, and $7.1 \%$ of philosophers of science whose papers are mainly cited in STEM fields. 
Table 4 - Distribution, by discipline, of authors whose philosophy of science articles are mostly cited in STEM fields

\begin{tabular}{|l|c|c|}
\hline Discipline & Number of authors & \% of authors \\
\hline Biology & 42 & 24.7 \\
\hline Medicine & 25 & 14.7 \\
\hline Physics & 18 & 10.6 \\
\hline Mathematics & 13 & 7.6 \\
\hline Engineering & 9 & 5.3 \\
\hline Other STEM disciplines & 3 & 1.8 \\
\hline Bioethics & 22 & 12.9 \\
\hline Philosophy of science & 12 & 7.1 \\
\hline Philosophy & 16 & 9.4 \\
\hline Social sciences & 10 & 5.7 \\
\hline
\end{tabular}

The community at the center of the network is composed of 200 authors whose philosophy of science articles receive citations from both philosophy of science and STEM fields. Of these 200 authors, $79.5 \%$ are philosophers of science, $5 \%$ are philosophers mainly active in subfields other than philosophy of science, $15 \%$ are scientists, and $0.5 \%$ are social scientists. We categorized authors as philosophers of science, philosophers mainly active in subfields other than philosophy of science, or scientists based on the subfields and journals where they published the most frequently, the disciplines in which they received their $\mathrm{PhD}$, and their departmental affiliations. What make philosophers of science of this central community visible in both philosophy of science and STEM disciplines? An analysis of the publication and citation patterns of this limited group of 159 authors provides some answers, as shown in Table 5:

- 55 out of 159 philosophers of science from this community (34.6\%) also figure amongst the top-100 most cited authors in philosophy of science journals between 1980 and 2018.

- 48 philosophers of science (30.1\%) have published at least 5 peer-reviewed articles in STEM journals.

- 14 philosophers of science (8.8\%) belong to both previous categories (they are amongst the top-100 cited philosophers of science and have also published more than 5 STEM peer-reviewed articles).

- 27 philosophers of science (13.5\%) belong to none of these categories. 
- 15 philosophers of science (7.5\%) are active in the subfield of bioethics, especially medical ethics.

Overall, $79 \%$ of philosophers of science who get cited in both fields of philosophy of science and STEM are either highly cited authors in the field of philosophy of science or intervene frequently in science, through the frequent publication of peer-reviewed articles in journals of STEM disciplines. In other words, two main categories of philosophers of science are more likely to be cited by both scientists and philosophers of science: those who achieve high visibility in their own field (philosophy of science) may be able to extend this visibility to STEM fields, while those who publish frequently in STEM disciplines may also get their philosophy of science articles visible in STEM. The remaining of the central community is composed of philosophers and scientists: 10 philosophers who specialize in subfields other than philosophy of science compose $5 \%$ of the community, and 30 scientists, half of them biologists, compose $15 \%$ of the community. Finally, only one social scientist, Herbert A. Simon, is present in this community.

Table 5 - Distribution of philosophy of science authors who are cited by both philosophy of science and STEM disciplines

\begin{tabular}{|l|c|c|}
\hline Author category & Number of authors & \% of authors \\
\hline Top-100 cited philosophers of science & 55 & 27.5 \\
\hline $\begin{array}{l}\text { Philosophers of science with at least } 5 \\
\text { papers in STEM }\end{array}$ & 48 & 24.0 \\
\hline $\begin{array}{l}\text { Philosopher of science belonging to both } \\
\text { above categories }\end{array}$ & 14 & 7.0 \\
\hline Other philosophers of science & 27 & 13.5 \\
\hline $\begin{array}{l}\text { Philosophers (other than philosophers of } \\
\text { science) }\end{array}$ & 10 & 5.0 \\
\hline Bioethicists & 15 & 7.5 \\
\hline Scientists & 30 & 15.0 \\
\hline Social scientists & 1 & 0.5 \\
\hline Total & 200 & 100.0 \\
\hline
\end{tabular}


Figure 5 - Network of authors of philosophy of science articles cited at least 20 times in STEM or philosophy of science, 19802018

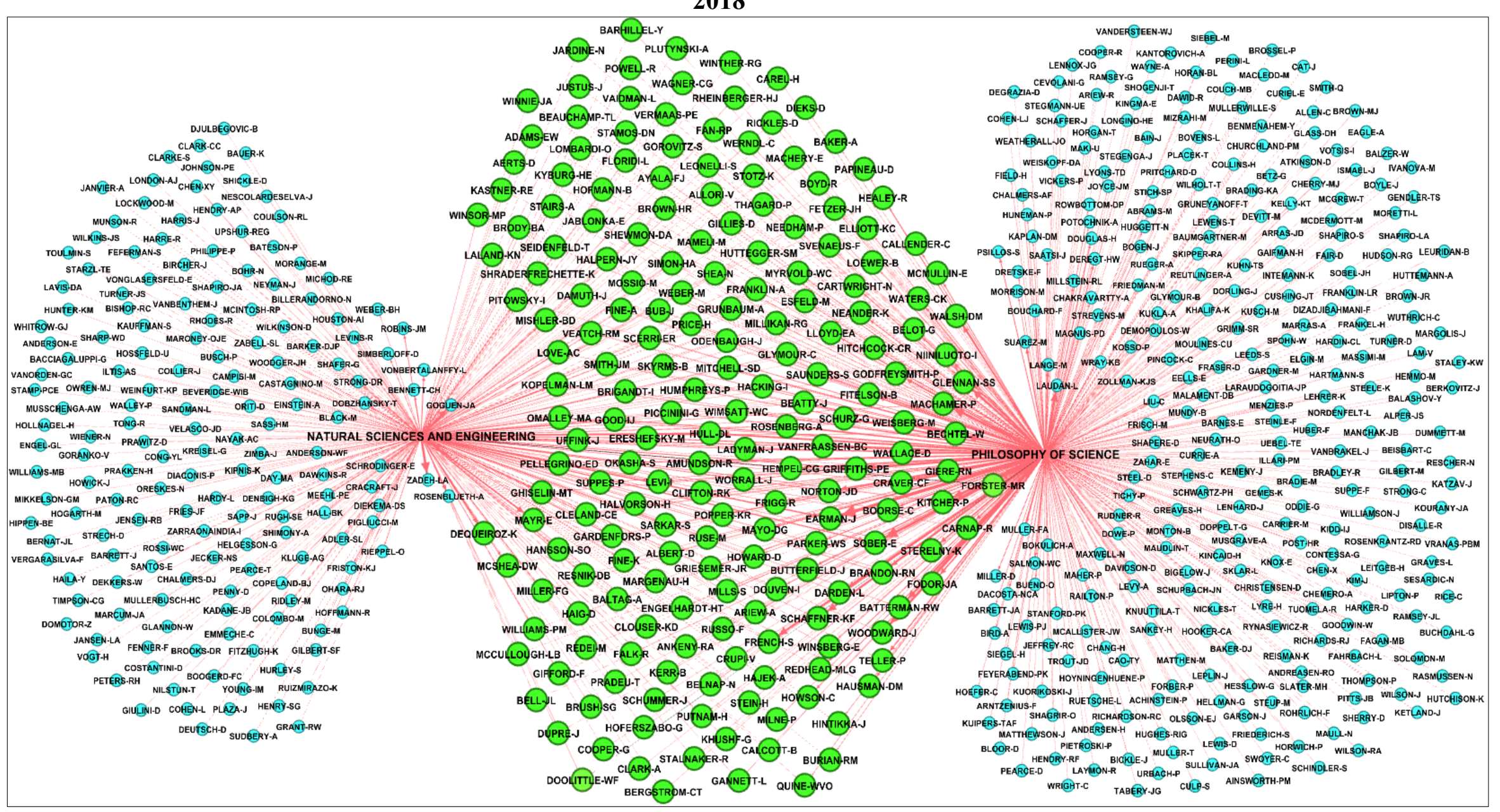




\section{Conclusion}

In this paper, we assessed the visibility of philosophy of science in the sciences at the level of disciplines, journals and authors. Analyzing all citations received by 17 major philosophy of science journals between 1980 and 2018, we first confirmed McLevey's et. al. finding (2018) that about half of citations received by the field of philosophy of science come from outside the field of philosophy. This share of external citations was found particularly important when compared to that of the rest of the field of philosophy. For the last four decades, philosophy of science has increased its visibility in a large number of STEM and SSH disciplines and, more importantly, spread its visibility among more journals and subfields, as demonstrated by the decreasing concentration of citations made by top-10 citing STEM and SSH journals to philosophy of science journals. These citations, however, are not evenly distributed among disciplines and journals, some having developed more affinities with philosophy of science than others. Even inside each discipline, citations made to philosophy of science are not evenly distributed. Obviously, the affinity between STEM and SSH citing journals and cited philosophy of science journals strongly depends on the topics addressed by both categories of journals. Finally, part of the visibility of philosophy of science in STEM disciplines can be explained by contributions made by scientists in philosophy of science journals. But we've also uncovered the existence of an important community of philosophers of science who get cited in both philosophy of science and STEM fields. The two main factors explaining the ability of these authors to transcend the boundaries of their field are: 1) achieving very high visibility inside the field philosophy of science, or: 2) publishing simultaneously in both science journals and philosophy of science journals.

The overarching message that comes out of our detailed analysis of the growing visibility of philosophy of science in other scientific fields is that, contrary to what many may think, philosophy of science as a specialized field is far from autarchic and closed on itself. On the contrary, its work is in fact quite visible in many other scientific disciplines. Our results also suggest that abstract and general discussions on the usefulness or not of philosophical reflections for the work of practicing scientists should take these empirical results into account in future discussion. 
This raises an important practical question: if one is convinced that philosophy of science can have a fruitful dialogue with the sciences, how may this dialogue be facilitated in practice? Part of the solution will certainly come from scientists themselves: by inviting philosophers of science to co-author papers, participate in scientific meetings, and so on. Needless to say, any influential scientist saying that philosophy of science has impacted their scientific research will be much more convincing to the scientific community than philosophers of science claiming that they have had such an impact. Another manner to increase our links with the sciences is the development of interdisciplinary curricula. Philosophers of science, especially the younger ones, already have, in most cases, a strong background in science. Yet this could be strengthened, and it could also be more valued in philosophy departments. In parallel, scientists should receive training in history and philosophy of science, not aiming to transform them or to challenge their practice, but rather to help them better understand how to use philosophers' unique competences to improve their scientific practice.

More work is now needed on the converse question: what is the place of the various sciences in philosophy of science? While the influence of individual scientists and scientific theories on the development of philosophy and philosophy of science has often been documented (e.g. Dewey 1910; Sanchez-Gonzalez 1990; Bitbol 1996; Stjernfelt 2011; Howard 2012), a macro-level analysis of the visibility of the sciences in

contemporary philosophy of science, based on citation flows and networks, though probably more difficult to implement, could reveal specific properties of the field of philosophy of science that have not been made visible in our study or have also been ignored by qualitative studies.

\section{References}

Ankeny, R., Chang. H., Boumans, M., \& Boon, M. (2011). Introduction: philosophy of science in practice. European Journal for Philosophy of Science, 1(3), 303-307. Andreotti, M., \& Maugeri, P. (2019). Does medicine need philosophy? Oral Diseases, 25(6), 1419-1422.

Bitbol, M. (1996). Schrödinger's philosophy of quantum mechanics. Boston: Kluwer Academic Publisher. 
Blondel, V. D., Guillaume, J. L., Lambiotte, R., \& Lefebvre, E. (2008). Fast unfolding of communities in large networks. Journal of Statistical Mechanics: Theory and experiments, 10, P10008.

Boniolo, G., \& Campaner, R. (2020). Life sciences for philosophers and philosophy for life scientists: What should we teach? Biological Theory, 15, 1-11.

Cherven, K. (2013). Network graph analysis and visualization with Gephi. Birmingham: Packt Publishing.

Cole, S., \& Cole J.R. (1967). Scientific output and recognition: A study in the operation of the reward system in science. American Sociological Review, 32(3), 377-390.

De Haro, S. (2020). Science and philosophy: A love-hate relationship. Foundations of Science, 25, 297-314.

Dewey, J. (1910). The influence of Darwin on philosophy and other essays in contemporary thought. New York: Henry Holt and Co.

Garfield, E. (1972). Citation analysis as a tool in journal evaluation - journals can be ranked by frequency and impact of citations for science policy studies. Science, 178(4060), 471-479.

Gingras, Y. (2016). Bibliometrics and Researh Evaluation. Uses and Abuses. Cambridge, Mass: MIT Press.

Gingras, Y., \& Khelfaoui, M. (2019). Do we need a book citation index for research evaluation? Research Evaluation, 28(4), 383-393.

Goguen, J.A. (1969). The logic of inexact concepts. Synthese, 19(3/4), 325-373.

Healy, K. (2013). A co-citation network for philosophy. Retrieved June 2, 2020, http://kieranhealy.org/blog/archives/2013/06/18/a-co-citation-network-for-philosophy/. Howard, D. (2012). Einstein and the development of twentieth-century philosophy of science. In Janssen, M, \& Lehner, C. The Cambridge Companion to Einstein. Cambridge: Cambridge University Press, 354-376.

Hull, D. L. (1994). Ernst Mayr's influence on the history and philosophy of biology: A personal memoir. Biology and Philosophy, 9, 375-386.

Kreuzman, H. (2001). A co-citation analysis of representative authors in philosophy: Examining the relationship between epistemologists and philosophers of science.

Scientometrics, 50(3), 525-539.

Laplane, L. et al. (2019). Why science needs philosophy. Proceedings of the National Academy of Science, 116(10), 3948-3952.

MacRoberts, M. H., \& MacRoberts, B. R. (1986). Quantitative measures of communication in science: A study of the formal level. Social Studies of Science, 16(1), 151-172.

Malaterre, C., Pulizzotto, D., \& Lareau, F. (2020). Revisiting three decades of Biology and Philosophy: A computational topic-modeling perspective. Biology and Philosophy, 35(5), https://doi.org/10.1007/s1053 9-019-9729-4. 
Malaterre, C., Chartier, J.-F., \& Pulizzotto, D. (2019). What Is this thing called Philosophy of Science? A computational topic-modeling perspective 1934-2015. HOPOS: The Journal of the International Society for the History of Philosophy of Science, 9(2), 215-243.

McLevey, J., Graham, A. V., McIlroy-Young, R., Browne, P., \& Plaisance, K. S. (2018). Interdisciplinarity and insularity in the diffusion of knowledge: An analysis of disciplinary boundaries between philosophy of science and the sciences. Scientometrics, 117(1), 331-349.

Merton, R.K. (1973). The sociology of science. Theoretical and empirical investigations. Chicago: University of Chicago Press.

Merton, R.K. (1988). The Matthew effect in science II: Cumulative advantage and the symbolism of intellectual property. Isis, 79(4), 606-623.

Milojevic, S. (2020). Nature, Science, and PNAS: disciplinary profiles and impact. Scientometrics, 123(3), p. 1301-1315.

Mizrahi, M. (2020). The case study method in philosophy of science: An Empirical Study. Perspectives on Science, 28(1), 63-88.

Moravscik, M., \& Murugesan, P. (1975). Some results on the function and quality of citations. Social Studies of Science, 5(1), 86-92.

Noichl, M. (2019). Modeling the structure of recent philosophy. Synthese, https://doi.org/10.1007/s11229-

019-02390-8.

Norton, J.D. (2010). How Hume and Mach helped Einstein find special relativity. In Dickson, M., \& Domski, M. Discourse on a new method: Reinvigorating the marriage of history and philosophy of science. Chicago: Open Court, 359-387.

Pernu, T.K. (2008). Philosophy and the front line of science. The Quarterly Review of Biology, 83(1), 29-36.

Petrovich, E., \& Bunomo, V. (2018). Reconstructing late analytical philosophy. A quantitative approach. Philosophical Inquiries, 6(1), 1-30.

Pigliucci, M. (2008). The borderlands between science and philosophy: an introduction. The Quarterly Review of Biology, 83(1), 7-15.

Pradeu, T., Lemoine, M., Khelfaoui, M., \& Gingras, Y. (submitted). Philosophy in science. The influence of philosophers of science on science.

Price, D.J.D. (1963). Little Science, Big Science, New York: Columbia University Press Price, D.J.D. (1976). A general theory of bibliometric and other cumulative advantage processes. Journal of the American Society for Information Science, 27(5), 292-306. Rovelli, C. (2018). Physics needs philosophy. Philosophy needs physics. Foundations of Physics, 48, 481-491.

Sanchez-Gonzalez, M.A. (1990). Medicine in John Locke's philosophy. Journal of Medicine and Philosophy, 15(6), 675-695. 
Stjernfelt, S. (2011). Simple animals and complex biology: Von Uexkull's two-fold influence on Cassirer's philosophy. Synthese, 179, 169-186.

Weingart, S. B. (2015). Finding the history and philosophy of science. Erkenntnis, 80(1), 201-213.

Wray, K.B., \& Bornmann, L. (2015). Philosophy of science viewed through the lens of "Referenced Publication Years Spectroscopy" (RPYS). Scientometrics, 102, 1987-1996. Wray, K. B. (2010). Philosophy of science: What are the key journals in the field? Erkenntnis, 72(3), 423-430.

Zadeh, L.A. (1975). Fuzzy logic and approximate reasoning. Synthese, 30(3/4), 407-428. 
Appendix A - Top-10 journals citing philosophy of science and top-5 cited philosophy of science journals (by discipline)

\begin{tabular}{|c|c|c|c|c|}
\hline \multicolumn{5}{|c|}{ PHILOSOPHY (CITING JOURNALS) } \\
\hline Rank & 1980-1989 & 1990-1999 & 2000-2009 & 2010-2018 \\
\hline 1. & PHILOSOPHICAL STUDIES & PHILOSOPHICAL STUDIES & PHILOSOPHICAL STUDIES & PHILOSOPHICAL STUDIES \\
\hline 2. & NOUS & NOUS & NOUS & $\begin{array}{l}\text { PHILOSOPHY AND } \\
\text { PHENOMENOLOGICAL } \\
\text { RESEARCH }\end{array}$ \\
\hline 3. & JOURNAL OF PHILOSOPHY & JOURNAL OF PHILOSOPHY & $\begin{array}{l}\text { PHILOSOPHY AND } \\
\text { PHENOMENOLOGICAL } \\
\text { RESEARCH }\end{array}$ & THEORIA \\
\hline 4. & $\begin{array}{l}\text { AUSTRALASIAN JOURNAL OF } \\
\text { PHILOSOPHY }\end{array}$ & $\begin{array}{l}\text { PHILOSOPHY AND } \\
\text { PHENOMENOLOGICAL } \\
\text { RESEARCH }\end{array}$ & JOURNAL OF PHILOSOPHY & NOUS \\
\hline 5. & $\begin{array}{l}\text { DIALOGUE-CANADIAN } \\
\text { PHILOSOPHICAL REVIEW }\end{array}$ & $\begin{array}{l}\text { AUSTRALASIAN JOURNAL OF } \\
\text { PHILOSOPHY }\end{array}$ & THEORIA & $\begin{array}{l}\text { JOURNAL OF PHILOSOPHICAL } \\
\text { LOGIC }\end{array}$ \\
\hline 6. & $\begin{array}{l}\text { CANADIAN JOURNAL OF } \\
\text { PHILOSOPHY }\end{array}$ & MIND & $\begin{array}{l}\text { AUSTRALASIAN JOURNAL OF } \\
\text { PHILOSOPHY }\end{array}$ & $\begin{array}{l}\text { AUSTRALASIAN JOURNAL OF } \\
\text { PHILOSOPHY }\end{array}$ \\
\hline 7. & $\begin{array}{l}\text { AMERICAN PHILOSOPHICAL } \\
\text { QUARTERLY }\end{array}$ & $\begin{array}{l}\text { SOUTHERN JOURNAL OF } \\
\text { PHILOSOPHY }\end{array}$ & DIALECTICA & AXIOMATHES \\
\hline 8. & $\begin{array}{l}\text { SOUTHERN JOURNAL OF } \\
\text { PHILOSOPHY }\end{array}$ & $\begin{array}{l}\text { ARBOR-CIENCIA PENSAMIENTO } \\
\text { Y CULTURA }\end{array}$ & MIND & MIND \\
\hline 9. & $\begin{array}{l}\text { MIDWEST STUDIES IN } \\
\text { PHILOSOPHY }\end{array}$ & DIALECTICA & MONIST & JOURNAL OF PHILOSOPHY \\
\hline 10. & $\begin{array}{l}\text { JOURNAL OF PHILOSOPHICAL } \\
\text { LOGIC }\end{array}$ & $\begin{array}{l}\text { JOURNAL OF PHILOSOPHICAL } \\
\text { LOGIC }\end{array}$ & $\begin{array}{l}\text { JOURNAL OF PHILOSOPHICAL } \\
\text { LOGIC }\end{array}$ & ANALYSIS \\
\hline \multicolumn{5}{|c|}{ CITED JOURNALS } \\
\hline Rank & 1980-1989 & 1990-1999 & 2000-2009 & 2010-2018 \\
\hline 1. & SYNTHESE & SYNTHESE & SYNTHESE & SYNTHESE \\
\hline 2. & PHILOSOPHY OF SCIENCE & PHILOSOPHY OF SCIENCE & PHILOSOPHY OF SCIENCE & PHILOSOPHY OF SCIENCE \\
\hline 3. & ERKENNTNIS & ERKENNTNIS & $\begin{array}{l}\text { THE BRITISH JOURNAL FOR THE } \\
\text { PHILOSOPHY OF SCIENCE }\end{array}$ & ERKENNTNIS \\
\hline 4. & $\begin{array}{l}\text { THE BRITISH JOURNAL FOR THE } \\
\text { PHILOSOPHY OF SCIENCE }\end{array}$ & $\begin{array}{l}\text { THE BRITISH JOURNAL FOR THE } \\
\text { PHILOSOPHY OF SCIENCE }\end{array}$ & ERKENNTNIS & $\begin{array}{l}\text { THE BRITISH JOURNAL FOR THE } \\
\text { PHILOSOPHY OF SCIENCE }\end{array}$ \\
\hline 5. & $\begin{array}{l}\text { STUDIES IN HISTORY AND } \\
\text { PHILOSOPHY OF SCIENCE }\end{array}$ & $\begin{array}{l}\text { STUDIES IN HISTORY AND } \\
\text { PHILOSOPHY OF SCIENCE }\end{array}$ & $\begin{array}{l}\text { STUDIES IN HISTORY AND } \\
\text { PHILOSOPHY OF SCIENCE }\end{array}$ & $\begin{array}{l}\text { STUDIES IN HISTORY AND } \\
\text { PHILOSOPHY OF SCIENCE }\end{array}$ \\
\hline
\end{tabular}




\begin{tabular}{|c|c|c|c|c|}
\hline \multicolumn{5}{|c|}{ BIOLOGY (CITING JOURNALS) } \\
\hline Rank & 1980-1989 & $1990-1999$ & $2000-2009$ & $2010-2018$ \\
\hline 1. & SYSTEMATIC ZOOLOGY & ACTA BIOTHEORETICA & ACTA BIOTHEORETICA & ACTA BIOTHEORETICA \\
\hline 2. & AMERICAN NATURALIST & $\begin{array}{l}\text { JOURNAL OF THEORETICAL } \\
\text { BIOLOGY }\end{array}$ & CLADISTICS & $\begin{array}{l}\text { JOURNAL OF THEORETICAL } \\
\text { BIOLOGY }\end{array}$ \\
\hline 3. & ACTA BIOTHEORETICA & SYSTEMATIC BIOLOGY & THEORY IN BIOSCIENCES & EVOLUTIONARY BIOLOGY \\
\hline 4. & $\begin{array}{l}\text { JOURNAL OF THEORETICAL } \\
\text { BIOLOGY }\end{array}$ & CLADISTICS & ZHURNAL OBSHCHEI BIOLOGII & THEORY IN BIOSCIENCES \\
\hline 5. & ECOLOGY & BIOSYSTEMS & $\begin{array}{l}\text { JOURNAL OF THEORETICAL } \\
\text { BIOLOGY }\end{array}$ & CLADISTICS \\
\hline 6. & AMERICAN ZOOLOGIST & ZHURNAL OBSHCHEI BIOLOGII & SYSTEMATIC BIOLOGY & EVOLUTION \\
\hline 7. & PALEOBIOLOGY & SYSTEMATIC BOTANY & EVOLUTION & BIOSYSTEMS \\
\hline 8. & OIKOS & THEORY IN BIOSCIENCES & QUART. REVIEW OF BIOLOGY & $\begin{array}{l}\text { JOURNAL OF EXPERIMENTAL } \\
\text { ZOOLOGY PART B }\end{array}$ \\
\hline 9. & TAXON & AMERICAN NATURALIST & ZOOLOGICA SCRIPTA & BIOLOGY DIRECT \\
\hline 10. & EVOLUTION & EVOLUTIONARY BIOLOGY & BIOSYSTEMS & $\begin{array}{l}\text { JOURNAL OF EVOLUTIONARY } \\
\text { BIOLOGY }\end{array}$ \\
\hline \multicolumn{5}{|c|}{ CITED JOURNALS } \\
\hline Rank & 1980-1989 & 1990-1999 & 2000-2009 & 2010-2018 \\
\hline 1. & SYNTHESE & BIOLOGY \& PHILOSOPHY & BIOLOGY \& PHILOSOPHY & BIOLOGY \& PHILOSOPHY \\
\hline 2. & PHILOSOPHY OF SCIENCE & PHILOSOPHY OF SCIENCE & PHILOSOPHY OF SCIENCE & PHILOSOPHY OF SCIENCE \\
\hline 3. & $\begin{array}{l}\text { THE BRITISH JOURNAL FOR THE } \\
\text { PHILOSOPHY OF SCIENCE }\end{array}$ & $\begin{array}{l}\text { THE BRITISH JOURNAL FOR THE } \\
\text { PHILOSOPHY OF SCIENCE }\end{array}$ & $\begin{array}{l}\text { THE BRITISH JOURNAL FOR THE } \\
\text { PHILOSOPHY OF SCIENCE }\end{array}$ & $\begin{array}{l}\text { STUDIES IN HISTORY AND } \\
\text { PHILOSOPHY OF SCIENCE - C }\end{array}$ \\
\hline 4. & BIOLOGY \& PHILOSOPHY & SYNTHESE & $\begin{array}{l}\text { STUDIES IN HISTORY AND } \\
\text { PHILOSOPHY OF SCIENCE - C }\end{array}$ & $\begin{array}{l}\text { THE BRITISH JOURNAL FOR THE } \\
\text { PHILOSOPHY OF SCIENCE }\end{array}$ \\
\hline 5. & $\begin{array}{l}\text { STUDIES IN HISTORY AND } \\
\text { PHILOSOPHY OF SCIENCE }\end{array}$ & $\begin{array}{l}\text { STUDIES IN HISTORY AND } \\
\text { PHILOSOPHY OF SCIENCE }\end{array}$ & SYNTHESE & SYNTHESE \\
\hline
\end{tabular}




\begin{tabular}{|c|c|c|c|c|}
\hline \multicolumn{5}{|c|}{ PHYSICS (CITING JOURNALS) } \\
\hline Rank & 1980-1989 & $1990-1999$ & $2000-2009$ & $2010-2018$ \\
\hline 1. & FOUNDATIONS OF PHYSICS & FOUNDATIONS OF PHYSICS & FOUNDATIONS OF PHYSICS & FOUNDATIONS OF PHYSICS \\
\hline 2. & AMERICAN JOURNAL OF PHYSICS & $\begin{array}{l}\text { INTERNATIONAL JOURNAL OF } \\
\text { THEORETICAL PHYSICS }\end{array}$ & $\begin{array}{l}\text { INTERNATIONAL JOURNAL OF } \\
\text { THEORETICAL PHYSICS }\end{array}$ & ENTROPY \\
\hline 3. & $\begin{array}{l}\text { JOURNAL OF MATHEMATICAL } \\
\text { PHYSICS }\end{array}$ & AMERICAN JOURNAL OF PHYSICS & $\begin{array}{l}\text { AMERICAN JOURNAL OF } \\
\text { PHYSICS }\end{array}$ & PHYSICAL REVIEW D \\
\hline 4. & $\begin{array}{l}\text { INTERNATIONAL JOURNAL OF } \\
\text { THEORETICAL PHYSICS }\end{array}$ & PHYSICAL REVIEW A & $\begin{array}{l}\text { FOUNDATIONS OF PHYSICS } \\
\text { LETTERS }\end{array}$ & PHYSICAL REVIEW A \\
\hline 5. & NUOVO CIMENTO B & $\begin{array}{l}\text { FOUNDATIONS OF PHYSICS } \\
\text { LETTERS }\end{array}$ & PHYSICAL REVIEW A & $\begin{array}{l}\text { INTERNATIONAL JOURNAL OF } \\
\text { THEORETICAL PHYSICS }\end{array}$ \\
\hline 6. & PHYSICS LETTERS A & PHYSICS LETTERS A & $\begin{array}{l}\text { CLASSICAL AND QUANTUM } \\
\text { GRAVITY }\end{array}$ & $\begin{array}{l}\text { PHILOSOPICAL TRANSACTIONS OF } \\
\text { THE ROYAL SOCIETY PART A }\end{array}$ \\
\hline 7. & $\begin{array}{l}\text { PHILOSOPICAL TRANSACTIONS } \\
\text { OF THE ROYAL SOCIETY PART A }\end{array}$ & PHYSICS ESSAYS & PHYSICS IN PERSPECTIVE & AMERICAN JOURNAL OF PHYSICS \\
\hline 8. & PHYSICAL REVIEW D & NUOVO CIMENTO B & PHYSICAL REVIEW E & PHYSICA A \\
\hline 9. & ANNALEN DER PHYSIK & PHYSICS REPORTS & PHYSICS LETTERS A & EUROPEAN PHYSICAL JOURNAL H \\
\hline 10. & PHYSICA D & JOURNAL OF PHYSICS A & $\begin{array}{l}\text { JOURNAL OF MATHEMATICAL } \\
\text { PHYSICS }\end{array}$ & $\begin{array}{l}\text { CLASSICAL AND QUANTUM } \\
\text { GRAVITY }\end{array}$ \\
\hline \multicolumn{5}{|c|}{ CITED JOURNALS } \\
\hline Rank & 1980-1989 & 1990-1999 & 2000-2009 & $2010-2018$ \\
\hline 1. & PHILOSOPHY OF SCIENCE & PHILOSOPHY OF SCIENCE & $\begin{array}{l}\text { STUDIES IN HISTORY AND } \\
\text { PHILOSOPHY OF SCIENCE - B }\end{array}$ & $\begin{array}{l}\text { STUDIES IN HISTORY AND } \\
\text { PHILOSOPHY OF SCIENCE - B }\end{array}$ \\
\hline 2. & SYNTHESE & $\begin{array}{l}\text { THE BRITISH JOURNAL FOR THE } \\
\text { PHILOSOPHY OF SCIENCE }\end{array}$ & $\begin{array}{l}\text { THE BRITISH JOURNAL FOR } \\
\text { THE PHILOSOPHY OF SCIENCE }\end{array}$ & PHILOSOPHY OF SCIENCE \\
\hline 3. & $\begin{array}{l}\text { THE BRITISH JOURNAL FOR THE } \\
\text { PHILOSOPHY OF SCIENCE }\end{array}$ & SYNTHESE & PHILOSOPHY OF SCIENCE & $\begin{array}{l}\text { THE BRITISH JOURNAL FOR THE } \\
\text { PHILOSOPHY OF SCIENCE }\end{array}$ \\
\hline 4. & $\begin{array}{l}\text { STUDIES IN HISTORY AND } \\
\text { PHILOSOPHY OF SCIENCE }\end{array}$ & $\begin{array}{l}\text { STUDIES IN HISTORY AND } \\
\text { PHILOSOPHY OF SCIENCE }\end{array}$ & SYNTHESE & SYNTHESE \\
\hline 5. & ERKENNTNIS & ERKENNTNIS & ERKENNTNIS & FOUNDATIONS OF SCIENCE \\
\hline
\end{tabular}




\begin{tabular}{|c|c|c|c|c|}
\hline \multicolumn{5}{|c|}{ ENGINEERING AND TECHNOLOGY (CITING JOURNALS) } \\
\hline Rank & 1980-1989 & 1990-1999 & $2000-2009$ & $2010-2018$ \\
\hline 1. & FUZZY SETS AND SYSTEMS & MINDS AND MACHINES & MINDS AND MACHINES & MINDS AND MACHINES \\
\hline 2. & ARTIFICIAL INTELLIGENCE & FUZZY SETS AND SYSTEMS & $\begin{array}{l}\text { LECTURE NOTES IN ARTIFICIAL } \\
\text { INTELLIGENCE }\end{array}$ & $\begin{array}{l}\text { INTERNATIONAL JOURNAL OF } \\
\text { APPROXIMATE REASONING }\end{array}$ \\
\hline 3. & $\begin{array}{l}\text { IEEE TRANSACTIONS ON } \\
\text { SYSTEMS MAN AND } \\
\text { CYBERNETICS } \\
\end{array}$ & ARTIFICIAL INTELLIGENCE & $\begin{array}{l}\text { LECTURE NOTES IN COMPUTER } \\
\text { SCIENCE }\end{array}$ & $\begin{array}{l}\text { JOURNAL OF LOGIC AND } \\
\text { COMPUTATION }\end{array}$ \\
\hline 4. & $\begin{array}{l}\text { INTERNATIONAL JOURNAL OF } \\
\text { GENERAL SYSTEMS }\end{array}$ & $\begin{array}{l}\text { INTERNATIONAL JOURNAL OF } \\
\text { INTELLIGENT SYSTEMS }\end{array}$ & $\begin{array}{l}\text { JOURNAL OF LOGIC AND } \\
\text { COMPUTATION }\end{array}$ & KYBERNETES \\
\hline 5. & $\begin{array}{l}\text { LECTURE NOTES IN COMPUTER } \\
\text { SCIENCE }\end{array}$ & $\begin{array}{l}\text { LECTURE NOTES IN ARTIFICIAL } \\
\text { INTELLIGENCE }\end{array}$ & ARTIFICIAL INTELLIGENCE & APPLIED ONTOLOGY \\
\hline 6. & $\begin{array}{l}\text { COMPUTERS \& MATHEMATICS } \\
\text { WITH APPLICATIONS }\end{array}$ & KYBERNETES & $\begin{array}{l}\text { JOURNAL OF EXP. \& THEOR. } \\
\text { ARTIFICIAL INTELLIGENCE }\end{array}$ & ARTIFICIAL INTELLIGENCE \\
\hline 7. & $\begin{array}{l}\text { IEEE TRANS. PATTERN } \\
\text { ANALYSIS AND MACHINE } \\
\text { INTELLIGENCE }\end{array}$ & $\begin{array}{l}\text { INTERNATIONAL JOURNAL OF } \\
\text { GENERAL SYSTEMS }\end{array}$ & FUZZY SETS AND SYSTEMS & $\begin{array}{l}\text { JOURNAL OF EXP. \& THEOR. } \\
\text { ARTIFICIAL INTELLIGENCE }\end{array}$ \\
\hline 8. & CYBERNETICA & $\begin{array}{l}\text { LECTURE NOTES IN COMPUTER } \\
\text { SCIENCE }\end{array}$ & $\begin{array}{l}\text { INTERNATIONAL JOURNAL OF } \\
\text { APPROXIMATE REASONING }\end{array}$ & COGNITIVE SYSTEMS RESEARCH \\
\hline 9. & $\begin{array}{l}\text { INTERNATIONAL JOURNAL OF } \\
\text { INTELLIGENT SYSTEMS }\end{array}$ & INFORMATION SCIENCES & KYBERNETES & $\begin{array}{l}\text { JOURNAL OF ARTIFICIAL } \\
\text { INTELLIGENCE RESEARCH }\end{array}$ \\
\hline 10. & INFORMATION SCIENCES & $\begin{array}{l}\text { JOURNAL OF EXP. \& THEOR. } \\
\text { ARTIFICIAL INTELLIGENCE }\end{array}$ & $\begin{array}{l}\text { THEORETICAL COMPUTER } \\
\text { SCIENCE }\end{array}$ & INFORMATION SCIENCES \\
\hline \multicolumn{5}{|c|}{ CITED JOURNALS } \\
\hline Rank & 1980-1989 & 1990-1999 & 2000-2009 & 2010-2018 \\
\hline 1. & SYNTHESE & SYNTHESE & SYNTHESE & SYNTHESE \\
\hline 2. & PHILOSOPHY OF SCIENCE & PHILOSOPHY OF SCIENCE & PHILOSOPHY OF SCIENCE & PHILOSOPHY OF SCIENCE \\
\hline 3. & $\begin{array}{l}\text { THE BRITISH JOURNAL FOR THE } \\
\text { PHILOSOPHY OF SCIENCE }\end{array}$ & $\begin{array}{l}\text { THE BRITISH JOURNAL FOR THE } \\
\text { PHILOSOPHY OF SCIENCE }\end{array}$ & $\begin{array}{l}\text { THE BRITISH JOURNAL FOR THE } \\
\text { PHILOSOPHY OF SCIENCE }\end{array}$ & $\begin{array}{l}\text { THE BRITISH JOURNAL FOR THE } \\
\text { PHILOSOPHY OF SCIENCE }\end{array}$ \\
\hline 4. & ERKENNTNIS & ERKENNTNIS & ERKENNTNIS & $\begin{array}{l}\text { STUDIES IN HISTORY AND } \\
\text { PHILOSOPHY OF SCIENCE }\end{array}$ \\
\hline 5. & $\begin{array}{l}\text { JOURNAL OF MEDICINE AND } \\
\text { PHILOSOPHY }\end{array}$ & $\begin{array}{l}\text { JOURNAL OF MEDICINE AND } \\
\text { PHILOSOPHY }\end{array}$ & $\begin{array}{l}\text { STUDIES IN HISTORY AND } \\
\text { PHILOSOPHY OF SCIENCE }\end{array}$ & ERKENNTNIS \\
\hline
\end{tabular}




\begin{tabular}{|c|c|c|c|c|}
\hline \multicolumn{5}{|c|}{ MATHEMATICS (CITING JOURNALS) } \\
\hline Rank & 1980-1989 & $1990-1999$ & $\begin{array}{r}2000-2009 \\
\end{array}$ & $2010-2018$ \\
\hline 1. & $\begin{array}{l}\text { JOURNAL OF THE AMERICAN } \\
\text { STATISTICAL ASSOCIATION }\end{array}$ & JOURNAL OF SYMBOLIC LOGIC & LOGIC JOURNAL OF THE IGPL & REVIEW OF SYMBOLIC LOGIC \\
\hline 2. & JOURNAL OF SYMBOLIC LOGIC & $\begin{array}{l}\text { JOURNAL OF STATISTICAL } \\
\text { PLANNING AND INFERENCE }\end{array}$ & REVIEW OF SYMBOLIC LOGIC & STUDIA LOGICA \\
\hline 3. & ANNALS OF STATISTICS & $\begin{array}{l}\text { ANNALS OF PURE AND APPLIED } \\
\text { LOGIC }\end{array}$ & FUNDAMENTA INFORMATICAE & LOGIC JOURNAL OF THE IGPL \\
\hline 4. & $\begin{array}{l}\text { ZEIT. FUR MATHEMATISCHE } \\
\text { LOGIK UND GRUND. DER } \\
\text { MATHEMATIK } \\
\end{array}$ & STATISTICAL SCIENCE & BULLETIN OF SYMBOLIC LOGIC & JOURNAL OF APPLIED LOGIC \\
\hline 5. & $\begin{array}{l}\text { INTERNATIONAL STATISTICAL } \\
\text { REVIEW }\end{array}$ & ANNALS OF STATISTICS & $\begin{array}{l}\text { APPLIED MATHEMATICS AND } \\
\text { COMPUTATION }\end{array}$ & COMPLEXITY \\
\hline 6. & $\begin{array}{l}\text { JOURNAL OF MATHEMATICAL } \\
\text { ANALYSIS AND APPLICATIONS }\end{array}$ & $\begin{array}{l}\text { JOURNAL OF THE AMERICAN } \\
\text { STATISTICAL ASSOCIATION }\end{array}$ & $\begin{array}{l}\text { ANNALS OF MATHEMATICS } \\
\text { AND ARTIFICIAL } \\
\text { INTELLIGENCE }\end{array}$ & $\begin{array}{l}\text { ANNALS OF PURE AND APPLIED } \\
\text { LOGIC }\end{array}$ \\
\hline 7. & $\begin{array}{l}\text { JOURNAL OF THE ROYAL } \\
\text { STATISTICAL SOCIETY SERIES B }\end{array}$ & $\begin{array}{l}\text { MATHEMATICAL LOGIC } \\
\text { QUARTERLY }\end{array}$ & $\begin{array}{l}\text { ANNALS OF PURE AND APPLIED } \\
\text { LOGIC }\end{array}$ & FUNDAMENTA INFORMATICAE \\
\hline 8. & $\begin{array}{l}\text { MATHEMATICAL AND } \\
\text { COMPUTER MODELLING }\end{array}$ & $\begin{array}{l}\text { JOURNAL OF THE ROYAL } \\
\text { STATISTICAL SOCIETY SERIES A }\end{array}$ & STATISTICAL SCIENCE & $\begin{array}{l}\text { NOTRE DAME JOURNAL OF } \\
\text { FORMAL LOGIC }\end{array}$ \\
\hline 9. & $\begin{array}{l}\text { JOURNAL OF STATISTICAL } \\
\text { COMPUTATION AND } \\
\text { SIMULATION } \\
\end{array}$ & $\begin{array}{l}\text { MATHEMATICAL } \\
\text { INTELLIGENCER }\end{array}$ & JOURNAL OF SYMBOLIC LOGIC & BULLETIN OF SYMBOLIC LOGIC \\
\hline 10. & MATHEMATICAL MODELLING & BULLETIN OF SYMBOLIC LOGIC & $\begin{array}{l}\text { INTERNATIONAL STATISTICAL } \\
\text { REVIEW }\end{array}$ & $\begin{array}{l}\text { ANNALS OF MATHEMATICS AND } \\
\text { ARTIFICIAL INTELLIGENCE }\end{array}$ \\
\hline \multicolumn{5}{|c|}{ CITED JOURNALS } \\
\hline Rank & 1980-1989 & 1990-1999 & 2000-2009 & 2010-2018 \\
\hline 1. & SYNTHESE & SYNTHESE & SYNTHESE & SYNTHESE \\
\hline 2. & PHILOSOPHY OF SCIENCE & $\begin{array}{l}\text { THE BRITISH JOURNAL FOR THE } \\
\text { PHILOSOPHY OF SCIENCE }\end{array}$ & $\begin{array}{l}\text { PHILOSOPHY OF SCIENCE } \\
\end{array}$ & PHILOSOPHY OF SCIENCE \\
\hline 3. & $\begin{array}{l}\text { THE BRITISH JOURNAL FOR THE } \\
\text { PHILOSOPHY OF SCIENCE }\end{array}$ & PHILOSOPHY OF SCIENCE & $\begin{array}{l}\text { THE BRITISH JOURNAL FOR THE } \\
\text { PHILOSOPHY OF SCIENCE }\end{array}$ & ERKENNTNIS \\
\hline 4. & ERKENNTNIS & ERKENNTNIS & ERKENNTNIS & $\begin{array}{l}\text { THE BRITISH JOURNAL FOR THE } \\
\text { PHILOSOPHY OF SCIENCE }\end{array}$ \\
\hline 5. & $\begin{array}{l}\text { JOURNAL OF MEDICINE AND } \\
\text { PHILOSOPHY }\end{array}$ & $\begin{array}{l}\text { JOURNAL OF MEDICINE AND } \\
\text { PHILOSOPHY }\end{array}$ & $\begin{array}{l}\text { STUDIES IN HISTORY AND } \\
\text { PHILOSOPHY OF SCIENCE }\end{array}$ & $\begin{array}{l}\text { STUDIES IN HISTORY AND } \\
\text { PHILOSOPHY OF SCIENCE }\end{array}$ \\
\hline
\end{tabular}




\begin{tabular}{|c|c|c|c|c|}
\hline \multicolumn{5}{|c|}{ MEDICINE (CITING JOURNALS) } \\
\hline Rank & 1980-1989 & 1990-1999 & $2000-2009$ & $2010-2018$ \\
\hline 1. & $\begin{array}{l}\text { PERSPECTIVES IN BIOLOGY } \\
\text { AND MEDICINE }\end{array}$ & $\begin{array}{l}\text { PERSPECTIVES IN BIOLOGY AND } \\
\text { MEDICINE }\end{array}$ & $\begin{array}{l}\text { PERSPECTIVES IN BIOLOGY AND } \\
\text { MEDICINE }\end{array}$ & $\begin{array}{l}\text { JOURNAL OF EVALUATION IN } \\
\text { CLINICAL PRACTICE }\end{array}$ \\
\hline 2. & $\begin{array}{l}\text { JOURNAL OF THE AMERICAN } \\
\text { MEDICAL ASSOCIATION }\end{array}$ & ANNALS OF INTERNAL MEDICINE & $\begin{array}{l}\text { JOURNAL OF EVALUATION IN } \\
\text { CLINICAL PRACTICE }\end{array}$ & $\begin{array}{l}\text { PERSPECTIVES IN BIOLOGY AND } \\
\text { MEDICINE }\end{array}$ \\
\hline 3. & $\begin{array}{l}\text { JOURNAL OF THE AMERICAN } \\
\text { GERIATRICS SOCIETY }\end{array}$ & $\begin{array}{l}\text { JOURNAL OF THE AMERICAN } \\
\text { MEDICAL ASSOCIATION }\end{array}$ & ACADEMIC MEDICINE & $\begin{array}{l}\text { FRONTIERS IN HUMAN } \\
\text { NEUROSCIENCE }\end{array}$ \\
\hline 4. & $\begin{array}{l}\text { ANNALS OF INTERNAL } \\
\text { MEDICINE }\end{array}$ & BRITISH MEDICAL JOURNAL & $\begin{array}{l}\text { JOURNAL OF EPIDEMIOLOGY } \\
\text { AND COMMUNITY HEALTH }\end{array}$ & NEUROQUANTOLOGY \\
\hline 5. & BRITISH MEDICAL JOURNAL & $\begin{array}{l}\text { JOURNAL OF THE AMERICAN } \\
\text { GERIATRICS SOCIETY }\end{array}$ & CRITICAL CARE MEDICINE & PEDIATRICS \\
\hline 6. & $\begin{array}{l}\text { AMERICAN JOURNAL OF } \\
\text { PSYCHIATRY }\end{array}$ & $\begin{array}{l}\text { ARCHIVES OF INTERNAL } \\
\text { MEDICINE }\end{array}$ & $\begin{array}{l}\text { JOURNAL OF THE AMERICAN } \\
\text { MEDICAL ASSOCIATION }\end{array}$ & BMJ OPEN \\
\hline 7. & MEDICAL DECISION MAKING & $\begin{array}{l}\text { CURRENT OPINION IN } \\
\text { PSYCHIATRY }\end{array}$ & PEDIATRICS & PROGRESS IN BRAIN RESEARCH \\
\hline 8. & JOURNAL OF FAMILY PRACTICE & $\begin{array}{l}\text { NEW ENGLAND JOURNAL OF } \\
\text { MEDICINE }\end{array}$ & $\begin{array}{l}\text { INT. JOURNAL OF TECHNOLOGY } \\
\text { ASSESSMENT IN HEALTH CARE }\end{array}$ & $\begin{array}{l}\text { JOURNAL OF PAIN AND } \\
\text { SYMPTOM MANAGEMENT }\end{array}$ \\
\hline 9. & $\begin{array}{l}\text { NEW ENGLAND JOURNAL OF } \\
\text { MEDICINE }\end{array}$ & ACADEMIC MEDICINE & $\begin{array}{l}\text { REPRODUCTIVE BIOMEDICINE } \\
\text { ONLINE }\end{array}$ & $\begin{array}{l}\text { INTERNATIONAL JOURNAL OF } \\
\text { EPIDEMIOLOGY }\end{array}$ \\
\hline 10. & $\begin{array}{l}\text { ARZNEIMITTEL- } \\
\text { FORSCHUNG/DRUG RESEARCH }\end{array}$ & LANCET & $\begin{array}{l}\text { JOURNAL OF GENERAL } \\
\text { INTERNAL MEDICINE }\end{array}$ & $\begin{array}{l}\text { NEUROSCIENCE AND } \\
\text { BIOBEHAVIORAL REVIEWS }\end{array}$ \\
\hline \multicolumn{5}{|c|}{ CITED JOURNALS } \\
\hline Rank & 1980-1989 & 1990-1999 & 2000-2009 & $2010-2018$ \\
\hline 1. & $\begin{array}{l}\text { JOURNAL OF MEDICINE AND } \\
\text { PHILOSOPHY }\end{array}$ & $\begin{array}{l}\text { JOURNAL OF MEDICINE AND } \\
\text { PHILOSOPHY }\end{array}$ & $\begin{array}{l}\text { JOURNAL OF MEDICINE AND } \\
\text { PHILOSOPHY }\end{array}$ & $\begin{array}{l}\text { JOURNAL OF MEDICINE AND } \\
\text { PHILOSOPHY }\end{array}$ \\
\hline 2. & PHILOSOPHY OF SCIENCE & PHILOSOPHY OF SCIENCE & $\begin{array}{l}\text { THEORETICAL MEDICINE AND } \\
\text { BIOETHICS }\end{array}$ & $\begin{array}{l}\text { MEDICINE HEALTH CARE AND } \\
\text { PHILOSOPHY }\end{array}$ \\
\hline 3. & SYNTHESE & $\begin{array}{l}\text { THE BRITISH JOURNAL FOR THE } \\
\text { PHILOSOPHY OF SCIENCE }\end{array}$ & $\begin{array}{l}\text { MEDICINE HEALTH CARE AND } \\
\text { PHILOSOPHY }\end{array}$ & $\begin{array}{l}\text { THEORETICAL MEDICINE AND } \\
\text { BIOETHICS }\end{array}$ \\
\hline 4. & $\begin{array}{l}\text { THE BRITISH JOURNAL FOR THE } \\
\text { PHILOSOPHY OF SCIENCE }\end{array}$ & $\begin{array}{l}\text { HISTORY AND PHILOSOPHY OF } \\
\text { THE LIFE SCIENCES }\end{array}$ & PHILOSOPHY OF SCIENCE & SYNTHESE \\
\hline 5. & $\begin{array}{l}\text { STUDIES IN HISTORY AND } \\
\text { PHILOSOPHY OF SCIENCE }\end{array}$ & SYNTHESE & $\begin{array}{l}\text { STUDIES IN HISTORY AND } \\
\text { PHILOSOPHY OF SCIENCE }\end{array}$ & PHILOSOPHY OF SCIENCE \\
\hline
\end{tabular}




\begin{tabular}{|c|c|c|c|c|}
\hline \multicolumn{5}{|c|}{ HEALTH (CITING JOURNALS) } \\
\hline Rank & 1980-1989 & 1990-1999 & $2000-2009$ & 2010-2018 \\
\hline 1. & SOCIAL SCIENCE \& MEDICINE & JOURNAL OF MEDICAL ETHICS & JOURNAL OF MEDICAL ETHICS & JOURNAL OF MEDICAL ETHICS \\
\hline 2. & HASTINGS CENTER REPORT & SOCIAL SCIENCE \& MEDICINE & BIOETHICS & BIOETHICS \\
\hline 3. & $\begin{array}{l}\text { CULTURE MEDICINE AND } \\
\text { PSYCHIATRY }\end{array}$ & BIOETHICS & $\begin{array}{l}\text { AMERICAN JOURNAL OF } \\
\text { BIOETHICS }\end{array}$ & $\begin{array}{l}\text { AMERICAN JOURNAL OF } \\
\text { BIOETHICS }\end{array}$ \\
\hline 4. & $\begin{array}{l}\text { JOURNAL OF HEALTH POLITICS } \\
\text { POLICY AND LAW }\end{array}$ & $\begin{array}{l}\text { CAMBRIDGE QUARTERLY OF } \\
\text { HEALTHCARE ETHICS }\end{array}$ & $\begin{array}{l}\text { CAMBRIDGE QUARTERLY OF } \\
\text { HEALTHCARE ETHICS }\end{array}$ & BMC MEDICAL ETHICS \\
\hline 5. & $\begin{array}{l}\text { AMERICAN JOURNAL OF } \\
\text { OCCUPATIONAL THERAPY }\end{array}$ & $\begin{array}{l}\text { THEORETICAL MEDICINE AND } \\
\text { BIOETHICS }\end{array}$ & SOCIAL SCIENCE \& MEDICINE & $\begin{array}{l}\text { CAMBRIDGE QUARTERLY OF } \\
\text { HEALTHCARE ETHICS }\end{array}$ \\
\hline 6. & JOURNAL OF MEDICAL ETHICS & HASTINGS CENTER REPORT & NURSING ETHICS & HEALTH CARE ANALYSIS \\
\hline 7. & $\begin{array}{l}\text { SOCIOLOGY OF HEALTH \& } \\
\text { ILLNESS }\end{array}$ & JOURNAL OF CLINICAL ETHICS & HEALTH CARE ANALYSIS & NURSING ETHICS \\
\hline 8. & PHYLON & $\begin{array}{l}\text { AMERICAN JOURNAL OF LAW \& } \\
\text { MEDICINE }\end{array}$ & HASTINGS CENTER REPORT & $\begin{array}{l}\text { JOURNAL OF BIOETHICAL } \\
\text { INQUIRY }\end{array}$ \\
\hline 9. & $\begin{array}{l}\text { JOURNAL OF RELIGION \& } \\
\text { HEALTH }\end{array}$ & NURSING ETHICS & JOURNAL OF CLINICAL ETHICS & SOCIAL SCIENCE \& MEDICINE \\
\hline 10. & MEDICAL CARE & $\begin{array}{l}\text { JOURNAL OF ADVANCED } \\
\text { NURSING }\end{array}$ & $\begin{array}{l}\text { JOURNAL OF ADVANCED } \\
\text { NURSING }\end{array}$ & NURSING PHILOSOPHY \\
\hline \multicolumn{5}{|c|}{ CITED JOURNALS } \\
\hline Rank & 1980-1989 & 1990-1999 & $2000-2009$ & $2010-2018$ \\
\hline 1. & $\begin{array}{l}\text { JOURNAL OF MEDICINE AND } \\
\text { PHILOSOPHY }\end{array}$ & $\begin{array}{l}\text { JOURNAL OF MEDICINE AND } \\
\text { PHILOSOPHY }\end{array}$ & $\begin{array}{l}\text { JOURNAL OF MEDICINE AND } \\
\text { PHILOSOPHY }\end{array}$ & $\begin{array}{l}\text { MEDICINE HEALTH CARE AND } \\
\text { PHILOSOPHY }\end{array}$ \\
\hline 2. & PHILOSOPHY OF SCIENCE & PHILOSOPHY OF SCIENCE & $\begin{array}{l}\text { MEDICINE HEALTH CARE AND } \\
\text { PHILOSOPHY }\end{array}$ & $\begin{array}{l}\text { JOURNAL OF MEDICINE AND } \\
\text { PHILOSOPHY }\end{array}$ \\
\hline 3. & $\begin{array}{l}\text { STUDIES IN HISTORY AND } \\
\text { PHILOSOPHY OF SCIENCE }\end{array}$ & $\begin{array}{l}\text { THE BRITISH JOURNAL FOR THE } \\
\text { PHILOSOPHY OF SCIENCE }\end{array}$ & $\begin{array}{l}\text { THEORETICAL MEDICINE AND } \\
\text { BIOETHICS }\end{array}$ & $\begin{array}{l}\text { THEORETICAL MEDICINE AND } \\
\text { BIOETHICS }\end{array}$ \\
\hline 4. & $\begin{array}{l}\text { THE BRITISH JOURNAL FOR THE } \\
\text { PHILOSOPHY OF SCIENCE }\end{array}$ & SYNTHESE & $\begin{array}{l}\text { STUDIES IN HISTORY AND } \\
\text { PHILOSOPHY OF SCIENCE }\end{array}$ & $\begin{array}{l}\text { STUDIES IN HISTORY AND } \\
\text { PHILOSOPHY OF SCIENCE }\end{array}$ \\
\hline 5. & SYNTHESE & $\begin{array}{l}\text { HISTORY AND PHILOSOPHY OF } \\
\text { THE LIFE SCIENCES }\end{array}$ & PHILOSOPHY OF SCIENCE & PHILOSOPHY OF SCIENCE \\
\hline
\end{tabular}




\begin{tabular}{|c|c|c|c|c|}
\hline \multicolumn{5}{|c|}{ PSYCHOLOGY (CITING JOURNALS) } \\
\hline Rank & 1980-1989 & $1990-1999$ & $2000-2009$ & $2010-2018$ \\
\hline 1. & $\begin{array}{l}\text { BEHAVIORAL AND BRAIN } \\
\text { SCIENCES }\end{array}$ & PHILOSOPHICAL PSYCHOLOGY & PHILOSOPHICAL PSYCHOLOGY & FRONTIERS IN PSYCHOLOGY \\
\hline 2. & BEHAVIOR AND PHILOSOPHY & $\begin{array}{l}\text { BEHAVIORAL AND BRAIN } \\
\text { SCIENCES }\end{array}$ & $\begin{array}{l}\text { BEHAVIORAL AND BRAIN } \\
\text { SCIENCES }\end{array}$ & PHILOSOPHICAL PSYCHOLOGY \\
\hline 3. & $\begin{array}{l}\text { JOURNAL OF MIND AND } \\
\text { BEHAVIOR }\end{array}$ & $\begin{array}{l}\text { JOURNAL OF MIND AND } \\
\text { BEHAVIOR }\end{array}$ & THEORY \& PSYCHOLOGY & $\begin{array}{l}\text { BEHAVIORAL AND BRAIN } \\
\text { SCIENCES }\end{array}$ \\
\hline 4. & $\begin{array}{l}\text { JOURNAL FOR THE THEORY OF } \\
\text { SOCIAL BEHAVIOUR }\end{array}$ & THEORY \& PSYCHOLOGY & $\begin{array}{l}\text { JOURNAL OF MIND AND } \\
\text { BEHAVIOR }\end{array}$ & THEORY \& PSYCHOLOGY \\
\hline 5. & $\begin{array}{l}\text { COMMUNICATION AND } \\
\text { COGNITION }\end{array}$ & BEHAVIOR AND PHILOSOPHY & COGNITIVE SCIENCE & COGNITIVE SCIENCE \\
\hline 6. & $\begin{array}{l}\text { INTERNATIONAL JOURNAL OF } \\
\text { MAN-MACHINE STUDIES }\end{array}$ & PSYCHOLOGICAL REPORTS & NEW IDEAS IN PSYCHOLOGY & NEW IDEAS IN PSYCHOLOGY \\
\hline 7. & COGNITION & COGNITION & $\begin{array}{l}\text { JOURNAL FOR THE THEORY OF } \\
\text { SOCIAL BEHAVIOUR }\end{array}$ & COGNITION \\
\hline 8. & $\begin{array}{l}\text { JOURNAL OF MATHEMATICAL } \\
\text { PSYCHOLOGY }\end{array}$ & $\begin{array}{l}\text { JOURNAL OF MATHEMATICAL } \\
\text { PSYCHOLOGY }\end{array}$ & BEHAVIOR AND PHILOSOPHY & $\begin{array}{l}\text { CONSCIOUSNESS AND } \\
\text { COGNITION }\end{array}$ \\
\hline 9. & AMERICAN PSYCHOLOGIST & NEW IDEAS IN PSYCHOLOGY & $\begin{array}{l}\text { CONSCIOUSNESS AND } \\
\text { COGNITION }\end{array}$ & TOPICS IN COGNITIVE SCIENCE \\
\hline 10. & $\begin{array}{l}\text { JOURNAL OF THE HISTORY OF } \\
\text { THE BEHAVIORAL SCIENCES }\end{array}$ & AMERICAN PSYCHOLOGIST & TRENDS IN COGNITIVE SCIENCES & $\begin{array}{l}\text { JOURNAL OF MATHEMATICAL } \\
\text { PSYCHOLOGY }\end{array}$ \\
\hline \multicolumn{5}{|c|}{ CITED JOURNALS } \\
\hline Rank & 1980-1989 & 1990-1999 & $2000-2009$ & $2010-2018$ \\
\hline 1. & $\begin{array}{l}\text { JOURNAL OF MEDICINE AND } \\
\text { PHILOSOPHY }\end{array}$ & PHILOSOPHY OF SCIENCE & PHILOSOPHY OF SCIENCE & SYNTHESE \\
\hline 2. & PHILOSOPHY OF SCIENCE & SYNTHESE & SYNTHESE & PHILOSOPHY OF SCIENCE \\
\hline 3. & $\begin{array}{l}\text { STUDIES IN HISTORY AND } \\
\text { PHILOSOPHY OF SCIENCE }\end{array}$ & $\begin{array}{l}\text { THE BRITISH JOURNAL FOR THE } \\
\text { PHILOSOPHY OF SCIENCE }\end{array}$ & $\begin{array}{l}\text { THE BRITISH JOURNAL FOR THE } \\
\text { PHILOSOPHY OF SCIENCE }\end{array}$ & BIOLOGY \& PHILOSOPHY \\
\hline 4. & $\begin{array}{l}\text { THE BRITISH JOURNAL FOR THE } \\
\text { PHILOSOPHY OF SCIENCE }\end{array}$ & $\begin{array}{l}\text { JOURNAL OF MEDICINE AND } \\
\text { PHILOSOPHY }\end{array}$ & BIOLOGY \& PHILOSOPHY & $\begin{array}{l}\text { THE BRITISH JOURNAL FOR THE } \\
\text { PHILOSOPHY OF SCIENCE }\end{array}$ \\
\hline 5. & SYNTHESE & $\begin{array}{l}\text { STUDIES IN HISTORY AND } \\
\text { PHILOSOPHY OF SCIENCE }\end{array}$ & $\begin{array}{l}\text { STUDIES IN HISTORY AND } \\
\text { PHILOSOPHY OF SCIENCE }\end{array}$ & $\begin{array}{l}\text { STUDIES IN HISTORY AND } \\
\text { PHILOSOPHY OF SCIENCE }\end{array}$ \\
\hline
\end{tabular}




\begin{tabular}{|c|c|c|c|c|}
\hline \multicolumn{5}{|c|}{ SCIENCE STUDIES (CITING JOURNALS) } \\
\hline Rank & 1980-1989 & 1990-1999 & $2000-2009$ & $2010-2018$ \\
\hline 1. & $\begin{array}{l}\text { PHILOSOPHY OF THE SOCIAL } \\
\text { SCIENCES }\end{array}$ & $\begin{array}{l}\text { JOURNAL OF THE HISTORY OF } \\
\text { BIOLOGY }\end{array}$ & $\begin{array}{l}\text { JOURNAL OF THE HISTORY OF } \\
\text { BIOLOGY }\end{array}$ & SCIENCE \& EDUCATION \\
\hline 2. & SOCIAL STUDIES OF SCIENCE & SOCIAL STUDIES OF SCIENCE & $\begin{array}{l}\text { PHILOSOPHY OF THE SOCIAL } \\
\text { SCIENCES }\end{array}$ & $\begin{array}{l}\text { PHILOSOPHY OF THE SOCIAL } \\
\text { SCIENCES }\end{array}$ \\
\hline 3. & SCIENTIA & ISIS & SCIENCE IN CONTEXT & $\begin{array}{l}\text { JOURNAL OF THE HISTORY OF } \\
\text { BIOLOGY }\end{array}$ \\
\hline 4. & ANNALS OF SCIENCE & HISTORY OF SCIENCE & ISIS & SOCIAL STUDIES OF SCIENCE \\
\hline 5. & $\begin{array}{l}\text { ARCHIVE FOR HISTORY OF } \\
\text { EXACT SCIENCES }\end{array}$ & ANNALS OF SCIENCE & HISTORY OF SCIENCE & $\begin{array}{l}\text { SCIENCE AND ENGINEERING } \\
\text { ETHICS }\end{array}$ \\
\hline 6. & ISIS & SCIENCE IN CONTEXT & SOCIAL STUDIES OF SCIENCE & ISIS \\
\hline 7. & $\begin{array}{l}\text { JOURNAL OF THE HISTORY OF } \\
\text { BIOLOGY }\end{array}$ & $\begin{array}{l}\text { BRITISH JOURNAL FOR THE } \\
\text { HISTORY OF SCIENCE }\end{array}$ & $\begin{array}{l}\text { BRITISH JOURNAL FOR THE } \\
\text { HISTORY OF SCIENCE }\end{array}$ & SCIENCE IN CONTEXT \\
\hline 8. & $\begin{array}{l}\text { BRITISH JOURNAL FOR THE } \\
\text { HISTORY OF SCIENCE }\end{array}$ & $\begin{array}{l}\text { HISTORY AND PHILOSOPHY OF } \\
\text { LOGIC }\end{array}$ & ANNALS OF SCIENCE & $\begin{array}{l}\text { HISTORICAL STUDIES IN THE } \\
\text { NATURAL SCIENCES }\end{array}$ \\
\hline 9. & HISTORY OF SCIENCE & $\begin{array}{l}\text { SCIENCE TECHNOLOGY \& } \\
\text { HUMAN VALUES }\end{array}$ & SCIENCE \& EDUCATION & $\begin{array}{l}\text { BRITISH JOURNAL FOR THE } \\
\text { HISTORY OF SCIENCE }\end{array}$ \\
\hline 10. & CENTAURUS & OSIRIS & $\begin{array}{l}\text { HIST. STUDIES IN THE PHYSICAL } \\
\text { AND BIOLOGICAL SCIENCES }\end{array}$ & $\begin{array}{l}\text { SCIENCE TECHNOLOGY \& } \\
\text { HUMAN VALUES }\end{array}$ \\
\hline \multicolumn{5}{|c|}{ CITED JOURNALS } \\
\hline Rank & 1980-1989 & 1990-1999 & $2000-2009$ & $2010-2018$ \\
\hline 1. & $\begin{array}{l}\text { STUDIES IN HISTORY AND } \\
\text { PHILOSOPHY OF SCIENCE }\end{array}$ & $\begin{array}{l}\text { STUDIES IN HISTORY AND } \\
\text { PHILOSOPHY OF SCIENCE }\end{array}$ & $\begin{array}{l}\text { STUDIES IN HISTORY AND } \\
\text { PHILOSOPHY OF SCIENCE - A }\end{array}$ & $\begin{array}{l}\text { STUDIES IN HISTORY AND } \\
\text { PHILOSOPHY OF SCIENCE - A }\end{array}$ \\
\hline 2. & PHILOSOPHY OF SCIENCE & SYNTHESE & PHILOSOPHY OF SCIENCE & PHILOSOPHY OF SCIENCE \\
\hline 3. & $\begin{array}{l}\text { THE BRITISH JOURNAL FOR THE } \\
\text { PHILOSOPHY OF SCIENCE }\end{array}$ & PHILOSOPHY OF SCIENCE & BIOLOGY \& PHILOSOPHY & SYNTHESE \\
\hline 4. & SYNTHESE & BIOLOGY \& PHILOSOPHY & $\begin{array}{l}\text { THE BRITISH JOURNAL FOR THE } \\
\text { PHILOSOPHY OF SCIENCE }\end{array}$ & BIOLOGY \& PHILOSOPHY \\
\hline 5. & ERKENNTNIS & $\begin{array}{l}\text { THE BRITISH JOURNAL FOR THE } \\
\text { PHILOSOPHY OF SCIENCE }\end{array}$ & $\begin{array}{l}\text { HISTORY AND PHILOSOPHY OF } \\
\text { THE LIFE SCIENCES }\end{array}$ & $\begin{array}{l}\text { THE BRITISH JOURNAL FOR THE } \\
\text { PHILOSOPHY OF SCIENCE }\end{array}$ \\
\hline
\end{tabular}

